\title{
Possibilities and Challenges for Quantitative Optical Sensing of Hydrogen Peroxide
}

\author{
Maria Moßhammer ${ }^{1}$, Michael Kühl ${ }^{1,2}$ and Klaus Koren ${ }^{1, *}$ \\ 1 Marine Biological Section, Department of Biology, University of Copenhagen, 3000 Helsingør, Denmark; \\ maria.mosshammer@bio.ku.dk (M.M.); mkuhl@bio.ku.dk (M.K.) \\ 2 Climate Change Cluster, University of Technology Sydney, Ultimo, NSW 2007, Australia \\ * Correspondence: klaus.koren@bio.ku.dk
}

Received: 11 September 2017; Accepted: 5 October 2017; Published: 11 October 2017

\begin{abstract}
Hydrogen peroxide $\left(\mathrm{H}_{2} \mathrm{O}_{2}\right)$ plays a key role in many biological processes spanning from coral bleaching, over cell signaling to aging. However, exact quantitative assessments of concentrations and dynamics of $\mathrm{H}_{2} \mathrm{O}_{2}$ remain challenging due to methodological limitationsespecially at very low (sub $\mu \mathrm{M})$ concentrations. Most published optical detection schemes for $\mathrm{H}_{2} \mathrm{O}_{2}$ suffer from irreversibility, cross sensitivity to other analytes such as other reactive oxygen species (ROS) or $\mathrm{pH}$, instability, temperature dependency or limitation to a specific medium. We review optical detection schemes for $\mathrm{H}_{2} \mathrm{O}_{2}$, compare their specific advantages and disadvantages, and discuss current challenges and new approaches for quantitative optical $\mathrm{H}_{2} \mathrm{O}_{2}$ detection, with a special focus on luminescence-based measurements. We also review published concentration ranges for $\mathrm{H}_{2} \mathrm{O}_{2}$ in natural habitats, and physiological concentrations in different biological samples to provide guidelines for future experiments and sensor development in biomedical and environmental science.
\end{abstract}

Keywords: hydrogen peroxide; $\mathrm{H}_{2} \mathrm{O}_{2}$; optical sensor; optical probes; reactive oxygen species (ROS); fluorescence; chemiluminescence

\section{Introduction}

Hydrogen peroxide $\left(\mathrm{H}_{2} \mathrm{O}_{2}\right)$ is a fascinating, yet under-investigated molecule. In the scientific literature it is referred to as a 'Jekyll and Hyde' molecule [1] and 'necessary evil' [2,3], due to its dual role in the human body. Hydrogen peroxide is linked to oxidative stress [4-7], and thus aging [5] and age-associated diseases such as Alzheimer's [8-10], Parkinson's disease [8,11,12], cancer [6,13,14], and cardiovascular disorder [4]. Studies have also linked lung diseases such as asthma and cystic fibrosis to elevated $\mathrm{H}_{2} \mathrm{O}_{2}$ concentrations in breath condensates [15]. However, $\mathrm{H}_{2} \mathrm{O}_{2}$ also plays beneficial or even vital roles as a cellular signaling agent $[7,16,17]$, transmitter of redox signals [18] or antibacterial agent in urine [19], just to name a few beneficial functions. Hydrogen peroxide in general is considered a cytotoxic agent $[7,19]$ above certain concentrations; however, $\mathrm{LD}_{50}$ values for different animals, plants and bacteria cells depend largely on the investigated cell type, its physiological state, and the exposure time [19-22].

Hydrogen peroxide does not only play an important physiological role in medicine and the human body, but is also relevant in other organisms and natural habitats such as coral reefs, where oxidative stress, and thus elevated $\mathrm{H}_{2} \mathrm{O}_{2}$ concentrations, have been linked to harmful coral bleaching events [23]. In natural waters, solar UV irradiance strongly influences $\mathrm{H}_{2} \mathrm{O}_{2}$ concentrations [24]. There is thus a growing interest and need for precise $\mathrm{H}_{2} \mathrm{O}_{2}$ measurements in aquatic systems subject to ongoing global climate change, where changes in solar irradiance can affect the formation of $\mathrm{H}_{2} \mathrm{O}_{2}$ e.g., in lake ecosystems or shallow coral reefs, and where photolysis of $\mathrm{H}_{2} \mathrm{O}_{2}$ by UV radiation can stimulate the formation of the highly reactive hydroxyl radical $\mathrm{OH}^{\bullet}$ [25]. In natural waters, $\mathrm{H}_{2} \mathrm{O}_{2}$ concentrations 
are thus typically highest in the photic zone and decrease with depth [26] from low $\mathrm{mM}$ to low $\mathrm{nM}$ (Supplementary Materials; Table S1).

Hydrogen peroxide is a reactive oxygen species (ROS) [1] (together with superoxide, hydroxyl radical, singlet oxygen, peroxynitrite, and hypochlorous acid [27]). However, in the absence of transition metals [19], selenoproteins and certain thiol proteins [18], $\mathrm{H}_{2} \mathrm{O}_{2}$ shows only low reactivity due to its high activation energy, and it does not readily react with most biological compounds despite being a strong oxidizing agent [18]. In comparison to other $\mathrm{ROS}, \mathrm{H}_{2} \mathrm{O}_{2}$ is therefore relatively stable [1] and long lived, while it remains reactive due to the fragile peroxide bond [28]. In ice cores taken in Greenland for example it was possible to detect $\mathrm{H}_{2} \mathrm{O}_{2}$ in depths correlating to several thousand years of age $[29,30]$. Nevertheless, it should not be overlooked that the hydroxyl radical formed by one-electron reduction of hydrogen peroxide is one of the strongest oxidizing agents, more reactive and less discriminating than $\mathrm{H}_{2} \mathrm{O}_{2}$ [18]. Apart from its reactivity, there are other factors complicating the continuous sensing of $\mathrm{H}_{2} \mathrm{O}_{2}$, such as its diffusion ability [31] and the high reactivity of other ROS or reactive nitrogen species (RNS; such as nitric oxide, or nitrous acid [27]) which frequently occur in the same environments [18,32] and complicate selective detection and quantification of $\mathrm{H}_{2} \mathrm{O}_{2}$.

Up front, we note that optical probes and optical sensors are not interchangeable terms, and describe different detection mechanisms. A probe is defined as a molecule undergoing a change of its optical properties in contact with a specific analyte [33], it is so to speak only the receptor part [34] of a sensor. A sensor has in addition to the receptor part also a transducer part [35]. In order to be described as 'chemical sensor' certain criteria have to be fulfilled as well. The system needs to deliver real time, on-line information on the analyte of interest. In order to do so, it needs to contain a read-out unit to give an analyzable signal [33]; thus, a single molecule interacting with $\mathrm{H}_{2} \mathrm{O}_{2}$ cannot be referred to as a sensor, but merely as a probe [36]. This is also referred to in the so called 'Cambridge definition': "Chemical sensors are miniaturized devices that can deliver real time and on-line information on the presence of specific compounds or ions in even complex samples" [34,36]. Generally speaking, the receptor part of the sensing system is responsible for transforming chemical information into energy of any form, which is then translated by the transducer into a signal that can be read out [35]. The ideal chemical sensor is described in the literature as an inexpensive, portable and foolproof device, which reacts instantaneous and with high selectivity to a specific analyte in any desired medium, producing a detectable signal output for any analyte concentration, to be precise and accurate and show long term stability [37].

In this paper, we review the current approaches and possibilities for quantitative optical monitoring of $\mathrm{H}_{2} \mathrm{O}_{2}$. There are many published approaches, but all of them have a number of limitations. Probably, the currently most advanced $\mathrm{H}_{2} \mathrm{O}_{2}$ sensor technology is based on electrochemical sensing. Such electrochemical systems, although still far from an ideal chemical sensor, enable continuous, reversible point measurements of $\mathrm{H}_{2} \mathrm{O}_{2}$ [38-41]. Details on electrochemical $\mathrm{H}_{2} \mathrm{O}_{2}$ sensors can be found in other recent reviews [41-43], while this review focuses on optical $\mathrm{H}_{2} \mathrm{O}_{2}$ detection.

In optical $\mathrm{H}_{2} \mathrm{O}_{2}$ detection, most systems involve the use of optical indicator probes, sometimes applied as pseudo-reversible or continuously regenerating systems, which will be elaborated in more detail below (Figure 1). As continuous sensing is very challenging, irreversible probe assays have found broad application. However, many traditional probes for $\mathrm{H}_{2} \mathrm{O}_{2}$ have been shown to react with other members of the ROS family as well [31], making them unsuitable for precise $\mathrm{H}_{2} \mathrm{O}_{2}$ detection and quantification. Additionally, most published $\mathrm{H}_{2} \mathrm{O}_{2}$ detection methods based on irreversible reactions only give insight into accumulative concentrations, rather than the actual $\mathrm{H}_{2} \mathrm{O}_{2}$ dynamics. In recent years several reviews have summarized the constantly growing array of probes for "sensing" of $\mathrm{H}_{2} \mathrm{O}_{2}$ (or ROS in general) [7,31,44-46]. In this review, we do not only aim to give a general overview, but specifically focus on continuous $\mathrm{H}_{2} \mathrm{O}_{2}$ sensing systems and a discussion of the problems and limitations of currently used methods. 


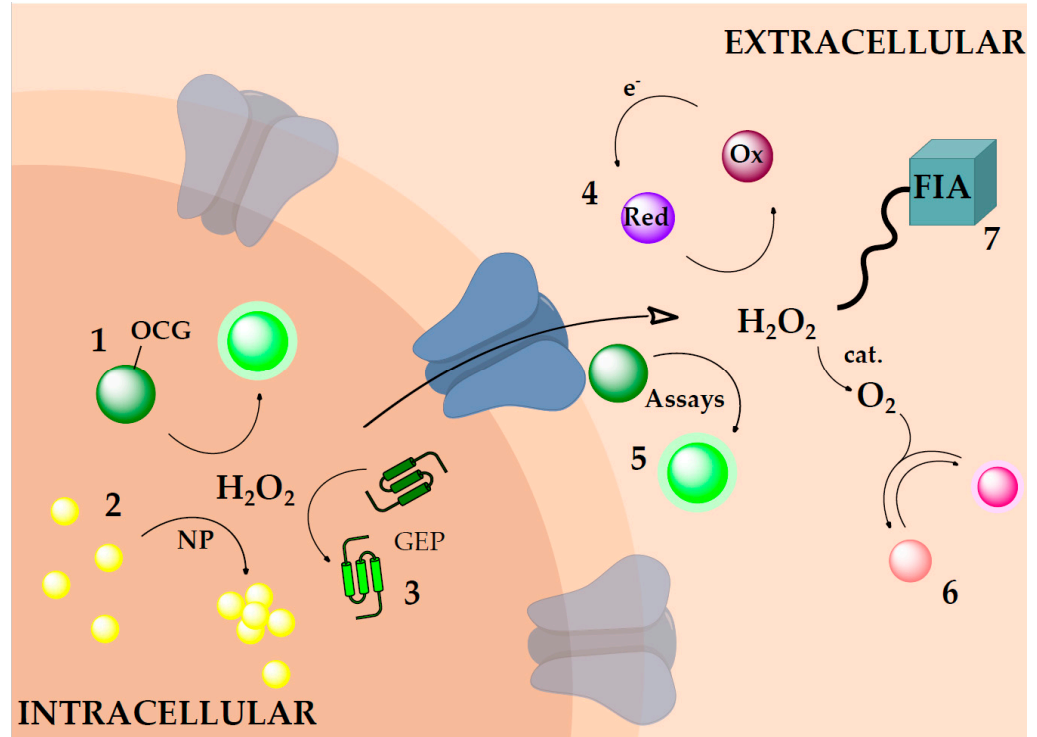

Figure 1. Possible optical $\mathrm{H}_{2} \mathrm{O}_{2}$ detection techniques for intra- or extracellular applications. The arrow in the middle indicates the ability of $\mathrm{H}_{2} \mathrm{O}_{2}$ to diffuse out of the cell e.g., via an aquaporin-mediated mechanism. (1) An oxidative cleaving group (OCG) is irreversibly cleaved; the product emits fluorescence after excitation with an external source; (2) Intracellular application of nanoparticles (NP), where the irreversible oxidation of NP forms an aggregate with changed optical properties; (3) Genetically encoded proteins (GEP) for selective $\mathrm{H}_{2} \mathrm{O}_{2}$ measurements; (4) Redox system being oxidized by $\mathrm{H}_{2} \mathrm{O}_{2}$ and reduced by an external reducing agent; (5) Luminescence assays for extracellular $\mathrm{H}_{2} \mathrm{O}_{2}$ determination; (6) Indirect detection of $\mathrm{H}_{2} \mathrm{O}_{2}$ via $\mathrm{O}_{2}$ measurement. (7) Flow injection analysis (FIA) with local sampling of extracellular $\mathrm{H}_{2} \mathrm{O}_{2}$ for external measurement.

\section{Intracellular Hydrogen Peroxide Measurement}

Measuring inside of cells is of high interest as understanding processes occurring on a cellular level is the key to understanding more complex processes in multicellular assemblages, such as biofilms, plants, animals or humans [47]. Intracellular $\mathrm{H}_{2} \mathrm{O}_{2}$ measurements present very different challenges compared to measurements in the extracellular environment [48], where the cellular microenvironment reacts rapidly to environmental changes to retain physiological steady-state. Cellular measurements thus require optical sensing at high temporal and spatial resolution, using biocompatible materials that can enter cells and with minimal impact on cell function. Fluorescent probes are frequently used for intracellular measurements, due to their fast response time, physical-non-invasiveness and high signals to background ratios [47]. After cell loading/staining, the probe signal is typically recorded by fluorescence microscopy or flow cytometry [48].

\subsection{Oxidative Cleavage-Based Probes}

Many intracellular probes for $\mathrm{H}_{2} \mathrm{O}_{2}$ detection rely on the irreversible reaction of $\mathrm{H}_{2} \mathrm{O}_{2}$ with an indicator molecule, which results in a change of the optical properties-usually an increase or decrease in fluorescence intensity [49]. Most published $\mathrm{H}_{2} \mathrm{O}_{2}$ probes, however, are not specific and show strong cross-sensitivities to other ROS or RNS [31]. One of the main employed mechanisms is the oxidative cleavage reaction [49] (Figure 2).

Usually, a 'selectively' cleavable group is attached to an indicator dye molecule such as coumarin, anthracene, BODIPY, cyanine, fluorescein, resorufin or rhodamine [48-51] (Figure 3). The selected dye determines the spectral range of the probe. While a large variety of probes exist that emit throughout the entire electromagnetic spectrum from UV to near infra-red (NIR), it is rather surprising that many recently published probes still rely on inherently $\mathrm{pH}$-sensitive indicators such as fluorescein (phenolic 
$\mathrm{pK}_{\mathrm{a}}$ 6.31-6.80 of the monoanion and dianione; two relevant species in aqueous solutions [52]) and resorufin (pKa 5.8; fluorescent at $\mathrm{pH}>7$ ) [53]). For reliable $\mathrm{H}_{2} \mathrm{O}_{2}$ detection with such dyes the $\mathrm{pH}$ (and changes in the $\mathrm{pH}$ ) of the sample need to be taken into consideration or buffered. Without simultaneous determination of cellular $\mathrm{pH}$, the quantification of $\mathrm{H}_{2} \mathrm{O}_{2}$ concentrations with such probes is thus prone to large uncertainty.

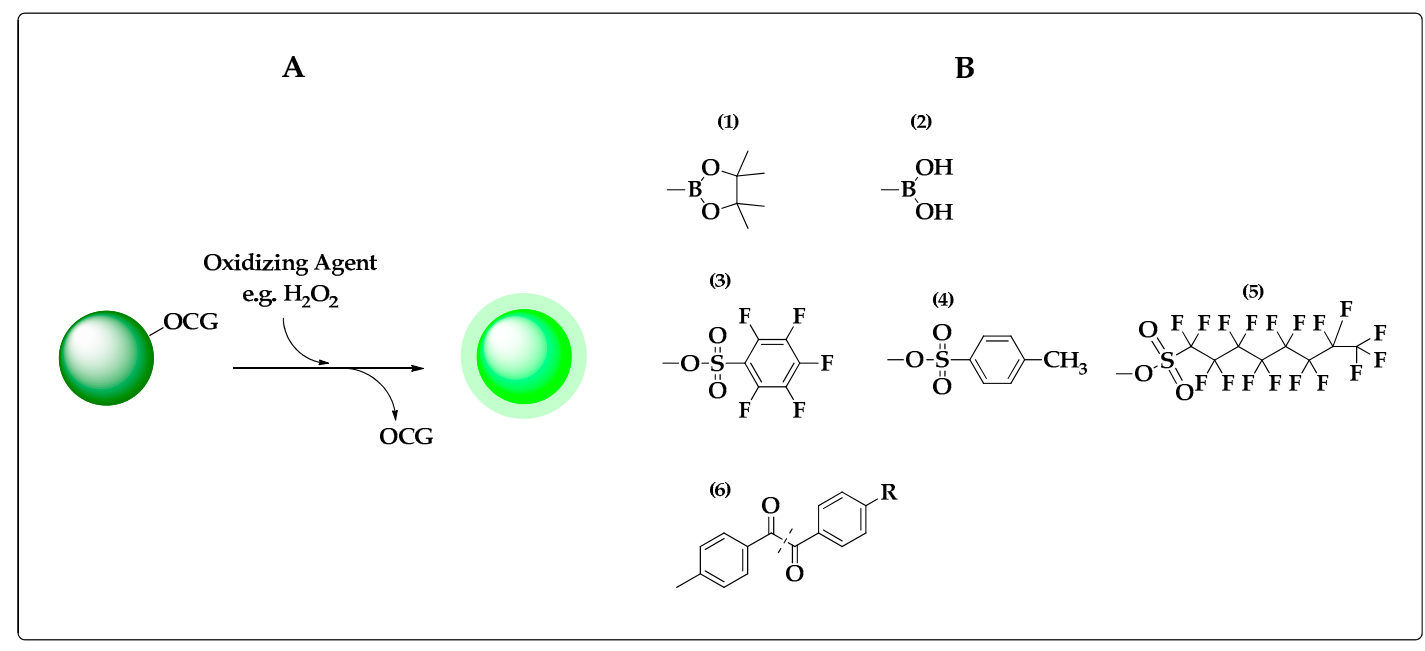

Figure 2. Oxidative cleavage reaction for $\mathrm{H}_{2} \mathrm{O}_{2}$ detection. (A) Schematic representation of the oxidative cleavage of a quenching group (oxidative cleavage group (OCG)) from a dye molecule (green). The product can be excited and emits light at a specific wavelength; (B) Frequently used OCG for $\mathrm{H}_{2} \mathrm{O}_{2}$ detection; (1) and (2) are boronate-based, (3-5) are sulfonate based; and (6) is based on the insertion of $\mathrm{H}_{2} \mathrm{O}_{2}$ and subsequent cleaving of the $\mathrm{C}-\mathrm{C}$ bond (indicated by dashed line).

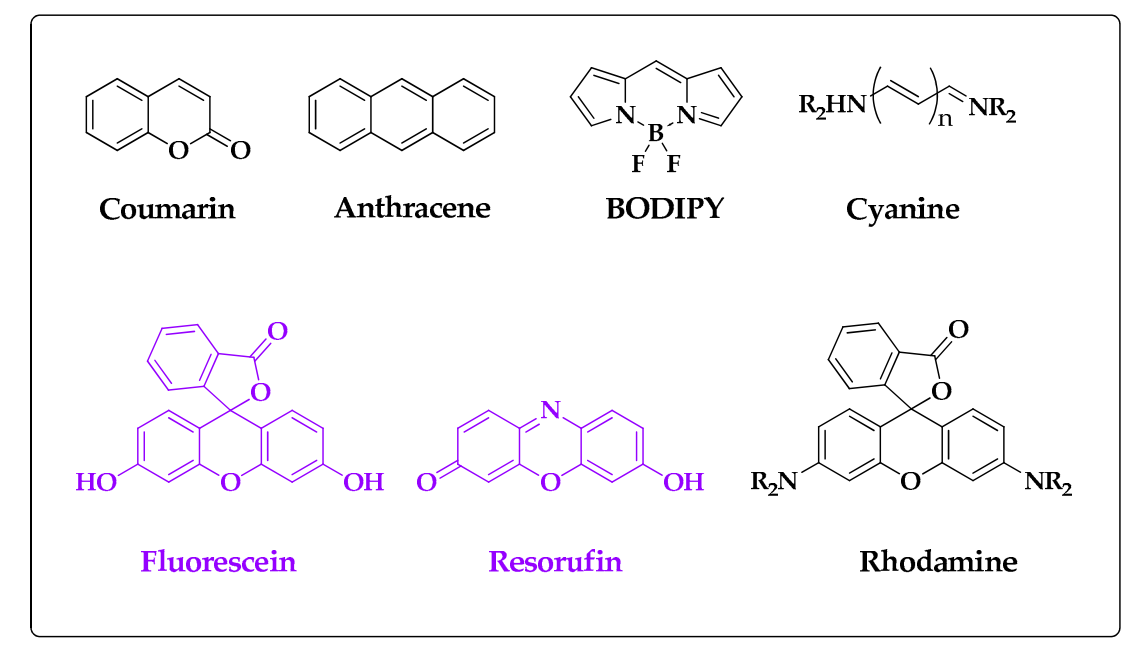

Figure 3. Frequently used dyes for probe synthesis and bioimaging of $\mathrm{H}_{2} \mathrm{O}_{2}$ in biological systems such as cells or extracellular fluids. The purple color highlights $\mathrm{pH}$ sensitive dyes.

When it comes to choice of the oxidative cleavage groups (OCGs), there are also many possibilities and many different detection schemes have been proposed in the literature [49,54,55]. Here we focus only on a few examples, but note that the points listed below also apply to most other OCGs (Figure 2). Boronate-based fluorescent probes (Figure 2; (1) and (2)), gained a lot of attention for their apparent ability to detect $\mathrm{H}_{2} \mathrm{O}_{2}$ selectively over other ROS [6,50,56-58]. However, several studies have shown that boronate-based fluorescent probes react almost a million times faster with peroxynitrite $\left(\mathrm{ONOO}^{-}\right)$[59], 5000 times faster with hypochlorous acid (HOCl) [59], and 1200 times faster with 
peroxymonophosphate [60] than they do with $\mathrm{H}_{2} \mathrm{O}_{2}$ (Figure 4). Furthermore, NO can together with superoxide oxidize boronates as well $[59,61]$. Many boronate-based probes use fluorescein as backbone dye [50,56], which become highly $\mathrm{pH}$ dependent after cleaving, making such measurements prone to $\mathrm{pH}$ related quenching artefacts.

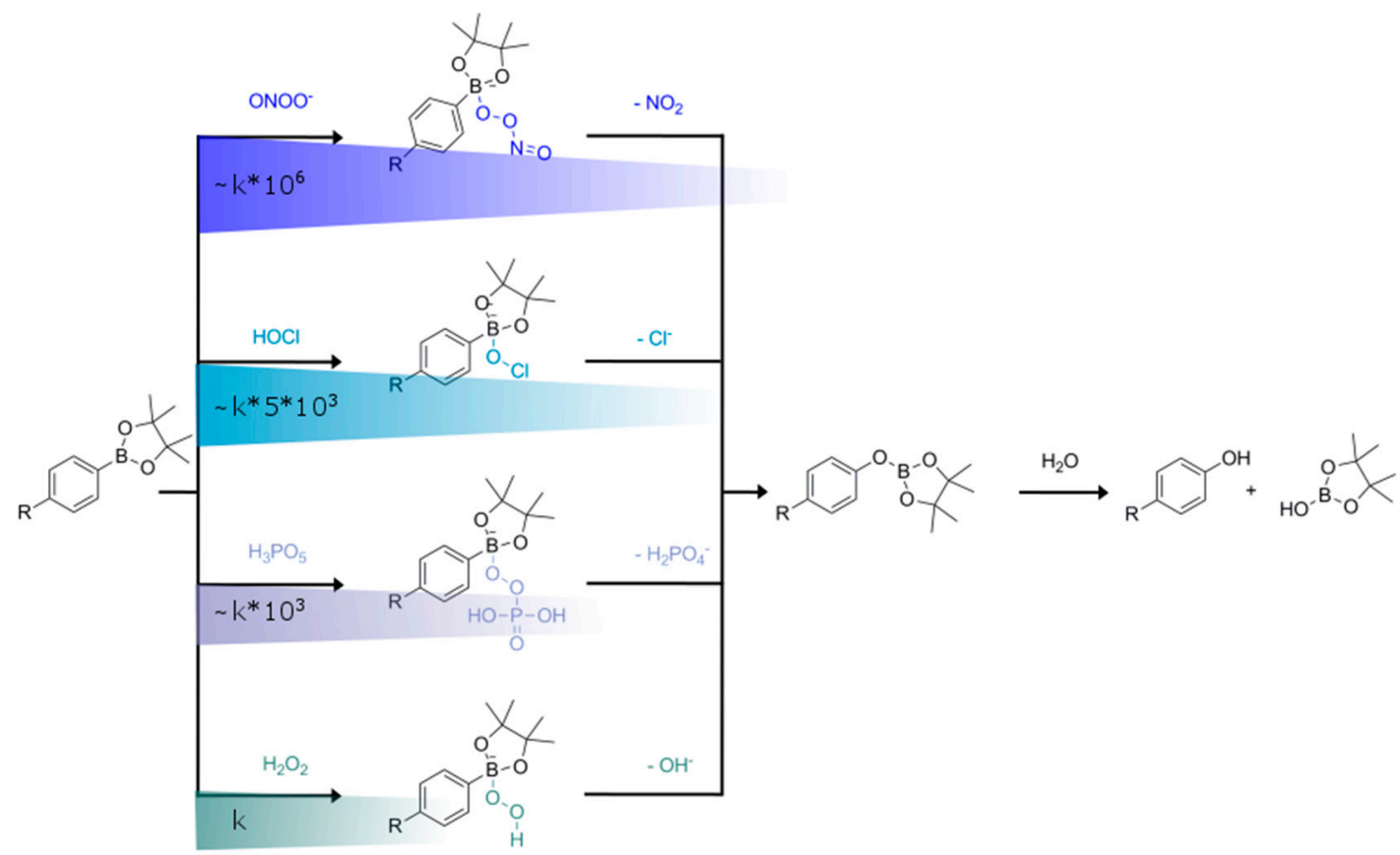

Figure 4. Oxidative cleavage reaction of boronate probes with peroxynitrite, hypochlorous acid, peroxymonophosphate and $\mathrm{H}_{2} \mathrm{O}_{2}$. The reaction rates depend on the- $\mathrm{R}$ group (e.g., fluorescein or resorufin and their substituents). The reactions are listed in order of decreasing reaction rates as found in the literature.

Another type of cleaving group is sulfonate-based (Figure 2; (3-5)). One example is the pentafluorobenzene ring (Figure 2; (3)) attached via a sulfonate group, which cleaves in the presence of $\mathrm{H}_{2} \mathrm{O}_{2}$. However, it also reacts with other ROS and RNS, and shows a higher fluorescent response with e.g., $\mathrm{O}_{2} \bullet$ [62]. Alternatively, the system is also published with two tosylate groups (Figure 2; (4)), which exhibited an ideal working $\mathrm{pH}$ range between $\mathrm{pH} 7.4$ and 7.8, thus indicating $\mathrm{pH}$ sensitivity. A third compound containing two sulfonate groups (perfluoro-octanesulfonate) (Figure 2; (5)) was shown to be sensitive to $\mathrm{H}_{2} \mathrm{O}_{2}$, with minor cross-sensitivity to ascorbic acid, gluthathione, esterase, $\mathrm{OCl}^{-}$and $\bullet \mathrm{OH}[63,64]$. Sulfonate cleaving groups are often coupled to fluorescein $[62,64,65]$. After cleaving, the remaining fluorescein is highly $\mathrm{pH}$ dependent due to the remaining hydroxyl groups, making such probes hard to use in real life samples.

A third example for a cleaving group is the oxidation of dibenzoyl (Figure 2; (6)). Different functional groups on the benzyl ring (e.g., electron-withdrawing groups such as $-\mathrm{NO}_{2}$ ) are necessary for a sufficient increase in fluorescence intensity, allowing the measurement of relatively low $\mathrm{H}_{2} \mathrm{O}_{2}$ concentrations. The $\mathrm{NO}_{2}$-substituted probe showed no response to $\mathrm{O}_{2}^{\bullet}, \bullet \mathrm{OH}^{\circ} \mathrm{OCl}^{-},{ }^{\bullet} \mathrm{NO}$, or ${ }^{1} \mathrm{O}_{2}$ and a moderate increase in fluorescence intensity to $\mathrm{ONOO}^{-}$[66]. Overall it can be concluded that not a single one of those oxidative cleavage groups is selective for $\mathrm{H}_{2} \mathrm{O}_{2}$. All of them show cross-sensitivities to other ROS, RNS or are $\mathrm{pH}$ dependent.

Another fluorescein-based probe relying on the release of a quencher ionophore was published by Song et al. [54]. The iron center is activated by $\mathrm{H}_{2} \mathrm{O}_{2}$ with subsequent $N$-dealkylation of the ligand, releasing the ionophore $(\mathrm{Fe})$ which can quench fluorescence. The probe is published to be selective over ${ }^{\bullet} \mathrm{OH}, \mathrm{OCl}^{-}, t$-BuOOH and $\mathrm{O}_{2}{ }^{\bullet}$, but shows minor interferences by ${ }^{\bullet} \mathrm{OH}$ and $t$-BuOOH. Additionally, 
after reacting with $\mathrm{H}_{2} \mathrm{O}_{2}$, this fluorescein-based probe is a $\mathrm{pH}$ indicator, but the authors reported that the fluorescence intensity was not affected by $\mathrm{pH}$ changes between $\mathrm{pH} 5.25$ and 7.81.

A frequently used probe-although its shortcomings have been discussed several times $[55,62]$ -is $2^{\prime}, 7^{\prime}$-dichlorodihydrofluorescein (DCFH) in combination with a catalyst (such as peroxidase, heme proteins or iron) $[67,68]$. As DCFH is not cell permeable, the diacetate ester (DA) is used, which can diffuse into the cell, where the acetate ester groups are cleaved by an esterase forming DCFH [55]. It has been reported that DCFH-DA is not very selective toward $\mathrm{H}_{2} \mathrm{O}_{2}$ but rather gives a measure of the total amount of oxidants present [62], and it is also known for its instability (photo-oxidation and photobleaching) [55]. Nonetheless, this probe is still widely used and claimed to quantify $\mathrm{H}_{2} \mathrm{O}_{2}$.

A major issue for the practical application of probes is the lack of retention of the reaction, which means that the moment they are in contact with a suitable oxidizing agent, the reaction is initiated and fluorescence increases. In a measurement context, this means there is no time for equilibration after the probe is added and a possible stress-response of the cell due to probe application cannot be ruled out. The time from adding the probe (by staining) to the actual experiment can span hours, wherein the 'background' signal keeps rising, due to reacting probe-molecules. It is difficult to ensure and demonstrate that the probe is evenly distributed in the sample and the absence of a signal might thus be a result of heterogeneous probe distribution or the absence of $\mathrm{H}_{2} \mathrm{O}_{2}$. Also calibration within the cell is not possible, and published values of $\mathrm{H}_{2} \mathrm{O}_{2}$ concentration should rather be regarded as estimates than absolute concentrations.

Additional important challenges for $\mathrm{H}_{2} \mathrm{O}_{2}$ sensing discussed in the literature encompass cytotoxicity, or chemical perturbation effects of some probes, the need for the dye to be water soluble and cell permeable, and the possible signal bias caused by binding of the dye to specific sites within the cell. Further drawbacks encompass autobleaching, interferences by autofluorescence of other structures present in the cell, which can also contribute to optical loss, and possibly most importantly, the lack of referencing [47]. In summary, we argue that current probes for $\mathrm{H}_{2} \mathrm{O}_{2}$ detection are not applicable for reliable quantitative concentration measurements. Such probes are typically used to compare different treatments of cells by comparing the relative fluorescence intensity. Nevertheless, such probes have generated important in vivo data and enable localization of $\mathrm{H}_{2} \mathrm{O}_{2}$ (or ROS) production within cells.

The development and application of ROS probes is a very active research field and has produced a large array of probes, and in recent years new designs have alleviated some of the shortcomings mentioned above. For example, reversible probes were developed [69-73] which can be oxidized and reduced in vivo enabling visualization of the cellular redox state. While this does not yield $\mathrm{H}_{2} \mathrm{O}_{2}$ concentration data, it enables studies of the dynamic balance between oxidants and reductants.

\subsection{Nanomaterials}

Nanoparticles are materials typically ranging in size between $1 \mathrm{~nm}$ and $100 \mathrm{~nm}$ (although definitions vary) and often exhibit distinct optical features. As the particle size, shape and composition all play a role in the physical and chemical properties of the nanomaterial [74], such indicators are quite tunable; especially by the broad range of possible surface modifications [75]. However, the described systems for $\mathrm{H}_{2} \mathrm{O}_{2}$ sensing are all irreversible probes and not 'real' sensors. Accordingly, such probes can only show increasing (accumulative) concentrations and real-time dynamic information is not possible. Various materials are used with different surface modifications. Advantages and disadvantages are pointed out on a few carefully chosen examples, while more information is available in other recent reviews [44].

Heavy metals are frequently used as base for nanoparticles, such as silver [76-80], gold [81-86], cadmium, zinc or tellurium $[87,88]$. Silver nanoparticles (Ag-NP) in general have a broad field of application, as they are antibacterial, antiviral, and antifungal. Nevertheless, the issue of their toxicity has not been fully resolved [76]. The oxidation (degradation) of $\mathrm{Ag}-\mathrm{NP}\left(\mathrm{Ag}^{\circ}\right.$ to $\left.\mathrm{Ag}^{+}\right)$by $\mathrm{H}_{2} \mathrm{O}_{2}$ was utilized for several different detection schemes [77,78,89]; however, one paper concludes that the oxidation of Ag-NPs is in fact much faster with $\mathrm{OCl}^{-}$than with $\mathrm{H}_{2} \mathrm{O}_{2}$ [90], thus oxidation-based 
Ag-NPs might not always be suitable for measuring $\mathrm{H}_{2} \mathrm{O}_{2}$. Gold nanoparticles (Au-NP) are also frequently applied in optical sensing due to their biocompatibility, size-tunable optical properties, stability, and ease of preparation and conjugation [81]. They can be used with [82] or without [86] surface modifications; however, they can also be used to quench the luminescence of an inert material by $\mathrm{H}_{2} \mathrm{O}_{2}$ initiated biocatalytic growth of Au-NP from Au nano-seeds [84]. This approach is also used to quench the fluorescence of e.g., dye-doped silica NPs with Au-NP seeds immobilized on their surface. The fluorescence intensities change when the Au-NPs grow on these seeds due to reduction of separately added $\mathrm{AuCl}_{4}{ }^{-}$in the presence of $\mathrm{H}_{2} \mathrm{O}_{2}$ [91]. However, also Au-NP based $\mathrm{H}_{2} \mathrm{O}_{2}$ detection can be affected by cross-sensitivities such as temperature [82,84], or $\mathrm{pH}$ [82] (but this overall depends on the specific surface modification). A system published by Li et al. [92] overcomes these interferences by a dual-emitting carbon quantum dot-gold nanocluster (CQD-AuNC) nanosatellite which is self-referencing. It is based on the blue emission of poly(ethylenimine)-capped CQDs (BPEI-CQD,) acting as reference and fluorescence quenching by $\mathrm{H}_{2} \mathrm{O}_{2}$ of the red emitting AuNC.

A subcategory of NPs are so-called quantum dots (QD), which can also be used for optical detection of $\mathrm{H}_{2} \mathrm{O}_{2}[87,88,93,94]$. Quantum dots are semiconducting NPs, which often consist of a semiconducting core and a semiconducting shell, in order to improve their optical properties $[95,96]$. They have broad excitation and narrow emission spectra, which are tunable, exhibit long fluorescent lifetimes, and are relatively immune to photo-bleaching as they do not consist of dye molecules [96]. Various different systems were successfully tested for $\mathrm{H}_{2} \mathrm{O}_{2}$ measurements, such as CdTe QDs, which, however, show a pH cross-sensitivity [88], various modified CdTe@ZnS-based QDs, which are differently interfered with by various chemical species (cysteine, $\mathrm{HClO}_{4}, \mathrm{GSH}$, urea, $\mathrm{NO}_{2}{ }^{-}, \mathrm{NO}_{3}{ }^{-}$, L-cystein, ${ }^{\bullet} \mathrm{OH}, \mathrm{TBHP}$, superoxide radical, $\mathrm{ONOO}^{-}$) [87] or $\mathrm{MoS}_{2}$ [94]. Water-soluble carbon quantum dots (CQD) can detect $\mathrm{H}_{2} \mathrm{O}_{2}$ on the basis of fluorescence quenching and have several advantages over semiconducting QDs in terms of low cytotoxicity, high photo-stability and biocompatibility [93].

Another class of nanoparticles used for intracellular measurements, referred to as PEBBLE sensors (photonic explorer for biomedical use with biologically localized embedding), are NP-based fluorescent sensor particles with a size range of $1-1000 \mathrm{~nm}$. They are easily tunable, have a nontoxic matrix and stand out intrinsic optical properties [47]. Not all of such PEBBLE sensors are selective for $\mathrm{H}_{2} \mathrm{O}_{2}$ over other ROS; but one system described by Kim et al. [97], the hydrophobic ormosil-DCFH PEBBLE, appears to be ( $\mathrm{DCFH}=2^{\prime}, 7^{\prime}$-dichlorodihydrofluorescin). Here competing reactive species such as peroxidase, the hydroxyl radical, superoxide, nitric oxide, peroxynitrite, hypochlorous acid, and the alkylperoxyl radical are kept out by different barrier systems. Nevertheless, a relatively strong change in fluorescence intensity can be observed in the presence of hypochlorous acid. The authors argue that this is 'only' due to $\mathrm{pH}$ changes caused by $\mathrm{HCl}$ production, as fluorescein-based dyes are more than anything excellent $\mathrm{pH}$ indicators.

There are also reports on chemiluminescence-based $\mathrm{H}_{2} \mathrm{O}_{2}$ sensitive NPs, which consist of a fluorescent dye, incorporated in a peroxalate ester containing polymer [98] or a dye and the peroxalate ester incorporated in a polymeric micelle [99]. The peroxalate ester reacts with $\mathrm{H}_{2} \mathrm{O}_{2}$ forming a highly energetic dioxetanedione, which-upon collision-transfers its energy to the dye molecule and degrades into two $\mathrm{CO}_{2}$ molecules. The dye molecule releases this excess energy by light emission. A minor cross sensitivity to superoxide was shown. Concentrations are, however, given in relative light units [98] as in vivo calibration is not possible with such systems, where one reagent (peroxalate) is consumed and thus continuously changes the system.

For nanomaterials it is very difficult to come to a general conclusion, as there is an enormous variability within them, due to their easily tunable surfaces, sizes, compositions, and metal combinations. Nanomaterials are definitely promising for $\mathrm{H}_{2} \mathrm{O}_{2}$ measurements. Nevertheless, the mentioned examples all show cross-sensitivities to other species, temperature or $\mathrm{pH}$ (or the authors did not test for such cross-sensitivity). Additionally, many nanomaterials rely on heavy metals, which are neither environmentally friendly nor very compatible with living cells, so even more precaution is necessary when evaluating the data. One difference [47] of nanoparticles-in comparison to probes-is 
that they do not necessarily rely on diffusion into the cell (and thus cell permeability), but can be inserted via nonspecific or receptor-mediated endocytosis [100].

\subsection{Genetically Encoded Probes-Fluorescent Proteins}

In order to overcome the disadvantage of irreversible probe systems and allow the measurement of dynamic changes, fluorescent proteins can be used [55]. These genetically encoded probes can be tailored to be chemically specific; targeting certain subcellular compartments to measure only in the area of interest, and allow ratiometric read out and dynamic measurements [101].

One example is the redox sensitive green fluorescent protein (GFP), which can be used with different mutations [55]. Redox-sensitive GFP (roGFP) can be modified to produce a working $\mathrm{H}_{2} \mathrm{O}_{2}$ sensor, by coupling it to yeast $\mathrm{H}_{2} \mathrm{O}_{2}$-sensing signaling peroxidase Orpl (roGFP-Orpl), which is not affected by $\mathrm{pH}$ changes in the physiological range [31].

Another example, HyPer, is described as a 'genetically encoded ratiometric fluorescence sensor for $\mathrm{H}_{2} \mathrm{O}_{2}$ ' [102]. HyPer is built by circularly permuted yellow fluorescent protein (cpYFP) inserted into the regulatory domain of OxyR, an E. coli protein devoted to $\mathrm{H}_{2} \mathrm{O}_{2}$ sensing. HyPer was shown to be selective for $\mathrm{H}_{2} \mathrm{O}_{2}$ over other ROS, but it is $\mathrm{pH}$ sensitive [103]. The change in fluorescence is induced by a redox-dependent conformational change within the protein [101]. Differently modified forms of HyPer are available such as HyPerRed, which emits in the red spectral region [104] and several are commercially available. HyPer allows for ratiometric measurements, it is fully reversible and can be modified to target specific subcellular compartments [55].

By attaching certain tags, specific subcellular locations can be targeted by genetically encoded probes [7]. Such probes can detect intracellular $\mathrm{H}_{2} \mathrm{O}_{2}$ concentrations in the nanomolar range, but they cannot measure absolute concentrations, or enable absolute in situ calibrations [101]. It is also not possible to measure $\mathrm{H}_{2} \mathrm{O}_{2}$ in extracellular environments or apply them on humans (as they are genetically encoded) [7]. Schäferling et al. [7] also conclude that roGFPs are not selective for $\mathrm{H}_{2} \mathrm{O}_{2}$, but can react with many oxidants.

\section{Extracellular Hydrogen Peroxide Measurements}

Extracellular measurements of $\mathrm{H}_{2} \mathrm{O}_{2}$ comprise $\mathrm{H}_{2} \mathrm{O}_{2}$ produced outside of the cell by membrane-associated enzymes, for example NAD $(\mathrm{P}) \mathrm{H}$ oxidases [105], but also by $\mathrm{H}_{2} \mathrm{O}_{2}$ diffusing out of the cell. It is known that $\mathrm{H}_{2} \mathrm{O}_{2}$ can be transported out of the cell via channels in the cell membrane or via protein-mediated mechanisms. However, it is debatable whether $\mathrm{H}_{2} \mathrm{O}_{2}$ is capable to freely diffuse out of the cell via the lipid bilayer or local changes in it [106]. An advantage of extracellular measurements is that the cells are not manipulated and therefore, the results are less prone to intracellular biotic effects imposed by the sensor chemistry itself. An additional advantage is that there are more options for detection and read-out, as the sample size is less restrictive and easier accessible.

\subsection{Chemiluminescent Reactions}

A common method to measure extracellular $\mathrm{H}_{2} \mathrm{O}_{2}$ involves chemiluminescent reactions. Chemiluminescent probes rely on a chemical reaction resulting in the emission of light. One of their major advantages is a usually very high signal-to-background ratio [107]. A chemiluminescence-based $\mathrm{H}_{2} \mathrm{O}_{2}$ sensing principle is based on chemistry first published in 1963 [108], and is still applied today e.g., in glow sticks [109]. Either bis(2,4,6-trichlorophenyl)-oxalate (TCPO) or bis(2,4,5-trichloro6-carbopentoxyphenyl)oxalate (CPPO) is used for the reaction with $\mathrm{H}_{2} \mathrm{O}_{2}$, which results in a highly reactive dioxetanedione $\left(\mathrm{C}_{2} \mathrm{O}_{4}\right)$. This highly energetic compound can transfer energy to a fluorescent dye, while decomposing into two $\mathrm{CO}_{2}$ molecules, causing chemiluminescence. The excited dye returns to its ground state by releasing energy in the form of light (chemiluminescent signal) $[108,109]$. This chemistry can be used with different dyes, to tune the spectral properties and was for example applied with perylene to measure in polar ice cores $[29,30]$ and rain water [110]. 
Another example is the reaction of $N, N^{\prime}$-dimethyl-9, $9^{\prime}$-biacridinium dinitrate (lucigenin) with $\mathrm{H}_{2} \mathrm{O}_{2}$ under alkaline conditions, but this reaction exhibits interferences from $\mathrm{Ag}(\mathrm{I}), \mathrm{Cu}$ (II), $\mathrm{Co}$ (II), creatinine and ascorbic acid-although the metal creatinine interferences could be eliminated by the presence of Brij-35 micelles [111]. They are nonetheless reported to react with other hydroperoxides [26] and superoxide anion radicals [112].

A novel compound for chemiluminescence-based $\mathrm{H}_{2} \mathrm{O}_{2}$ detection was reported by Ma et al. [113]. They describe the reaction of the newly synthesized 7-(4,6-dichloro-1,3,5-triazinylamino)4-methylcoumarin (DTMC). This reaction needs no catalyst or co-oxidant, but solely relies on the formation of DTMC- $\mathrm{H}_{2} \mathrm{O}_{2}$ (which however shows higher chemiluminescent intensities when adding cation surfactants). They also report that most transition metals apart from $\mathrm{Co}(\mathrm{II})$ and $\mathrm{Ag}(\mathrm{I})$, do not show catalytic interferences.

Other chemiluminescent reactions based on acridinium ester and luminol are described in Section 4, as they are frequently and successfully applied for continuous monitoring of $\mathrm{H}_{2} \mathrm{O}_{2}$ concentrations in natural samples.

\subsection{Kits for $\mathrm{H}_{2} \mathrm{O}_{2}$ Detection}

Assays are widely used for measuring extracellular $\mathrm{H}_{2} \mathrm{O}_{2}$ concentrations in biological fluids; they are well-established and many of them commercially available. These assays rely on a variety of measurement principles $[55,114]$, but here we focus on fluorescence-based assays. Most luminescence-based assays rely on the reaction of a peroxidase with $\mathrm{H}_{2} \mathrm{O}_{2}$ and the subsequent oxidation of a molecule to form a fluorescent product [48].

Many fluorescence assays are based on horse radish peroxidase (HRP) used in combination with a dye molecule. However, this reaction is only specific to the peroxide functional group and not $\mathrm{H}_{2} \mathrm{O}_{2}$ itself. HRP catalyzes the reaction, facilitating a follow-up reaction with an electron donor to either increase or decrease fluorescence [26]. Electron donors used to increase fluorescence are for example, $p$-hydroxyphenylacetic acid (POHPAA) $[26,115]$ and a variety of other compounds $[30,116]$, a decrease in fluorescence involves the use of e.g., scopoletin $[26,117,118]$. The reaction with POHPAA and HRP shows fluorescence increases in the presence of $\mathrm{H}_{2} \mathrm{O}_{2}$ as well as organic peroxides [115]. Not only scopoletin decreases the fluorescence in the presence of $\mathrm{HRP}$ and $\mathrm{H}_{2} \mathrm{O}_{2}$, but also phenols, or phenolic compounds in combination with HRP and other oxidized compounds. Moreover, the scopoletin method is described as highly $\mathrm{pH}$ dependent [26].

The reaction with homovanillic acid (HVA), HRP, and $\mathrm{H}_{2} \mathrm{O}_{2}$ is similar to POHPAA. Homovanillic acid is of the same ground structure as POHPAA with a 4-methoxy functional group [119]. HVA is oxidized by $\mathrm{H}_{2} \mathrm{O}_{2}$ and forms a highly fluorescent (but strongly $\mathrm{pH}$ dependent) dimer [120].

A frequently used fluorescent assay is based on HRP in combination with Amplex ${ }^{\circledR}$ Red or Ampliflu ${ }^{\mathrm{TM}}$ Red ( $\mathrm{N}$-acetyl-3,7-dihydroxyphenoxazine), which is a non-fluorescent resorufin derivative [55]. For $\mathrm{H}_{2} \mathrm{O}_{2}$ detection, $\mathrm{N}$-acetyl-3,7-dihydroxyphenoxazine is oxidized by the hydroxyl radical (HRP catalyzes the decomposition of $\mathrm{H}_{2} \mathrm{O}_{2}$ ) to the highly fluorescent resorufin $[55,121,122]$. One major advantage described in the literature is its emission peak which lies beyond most interfering background signals from other fluorescing biological samples, as well as its activity over a wide $\mathrm{pH}$ range (nevertheless, resorufin fluorescence is $\mathrm{pH}$ dependent) [55]. A study by Votyakova et al. [123] showed interference of this reaction by NADH and reduced glutathione, which also caused an increase in fluorescence. Additionally, peroxinitrite has been shown to oxidize Amplex ${ }^{\circledR}$ Red in the presence of HRP as well [124]. Different studies have also shown $\mathrm{H}_{2} \mathrm{O}_{2}$-independent oxidation pathways for Amplex ${ }^{\circledR}$ Red, with e.g., carboxylesterase [125] or peroxinitrite-derived radicals [124]. HRP has also been used in combination with dihydrorhodamine $6 \mathrm{G}$ to form the highly fluorescent rhodamine 6G [126]. However, dihydrorhodamine 6G as well as dihydrorhodamine 123 (and others) are not specific for $\mathrm{H}_{2} \mathrm{O}_{2}$ detection and can thus only be used as a general fluorescent probe for ROS in combination with HRP [46]. 
Assays are well suited for quantifying extracellular $\mathrm{H}_{2} \mathrm{O}_{2}$ and the diffusion of $\mathrm{H}_{2} \mathrm{O}_{2}$ out of the cell [48]. The user must however be aware that there can still be interfering species, such as NADH, reduced glutathione, other $\mathrm{ROS}, \mathrm{pH}$, or phenols; and such potential interferences need to be taken into consideration when planning an experiment. Unfortunately, the time resolution of assays is rather limited and samples have to be taken from the experiment prior to measurements.

\section{Intermediate Sensing Systems}

Some published $\mathrm{H}_{2} \mathrm{O}_{2}$ detection systems can be described as intermediate between a probe and a sensor, as they are closer to allowing continuous measurements, but are again based on an irreversible reaction, or a reaction that can be reversed by external factors. Some of the more well-established methods are described below.

\subsection{Flow Injection Analysis}

Flow injection analysis (FIA) for measuring $\mathrm{H}_{2} \mathrm{O}_{2}$ in natural waters has been used for decades and relies on different chemiluminescent reactions with $\mathrm{H}_{2} \mathrm{O}_{2}$ which are detected in a photomultiplier tube (PMT) as visualized in Figure 5. The reaction itself is not reversible, but due to the flow through system dynamic changes in $\mathrm{H}_{2} \mathrm{O}_{2}$ concentration can be detected. One major disadvantage is, however, the high analyte consumption making it difficult to apply the system on samples with limited volume.

FIA analysis of $\mathrm{H}_{2} \mathrm{O}_{2}$ relies on a few chemiluminescent reactions, where the two most frequently used reactions in the literature are (1) acridinium ester (10-methyl-9-( $p$-formylphenyl)-acridinium carboxylate trifluoromethanesulfonate) [127-131] and (2) luminol and a Co(II) catalyst [132-136]. Less frequently used reactions involve (3) TCPO (bis-(2,4,6-trichlorophenyl)oxalate) [110] or (4) the oxidation of phenol [137]. The acridinium ester-based reaction is strongly interfered with by $\mathrm{pH}$ (which is compensated by the use of a buffer solution) and Fe(II) at higher concentrations, which can be avoided by adding ferrozine to the flow system) [127]. The Co(II) catalyzed oxidation of luminol by $\mathrm{H}_{2} \mathrm{O}_{2}$ is also $\mathrm{pH}$ dependent (again with the option to compensate it by using a buffer solution), while $\mathrm{Fe}(\mathrm{II})$ is known to interfere as well as $\mathrm{Cr}(\mathrm{III}), \mathrm{Cr}(\mathrm{VI}), \mathrm{Co}(\mathrm{II}), \mathrm{Fe}(\mathrm{III}), \mathrm{Cu}(\mathrm{II})$, and $\mathrm{Mn}(\mathrm{II})$ at certain concentrations [132].

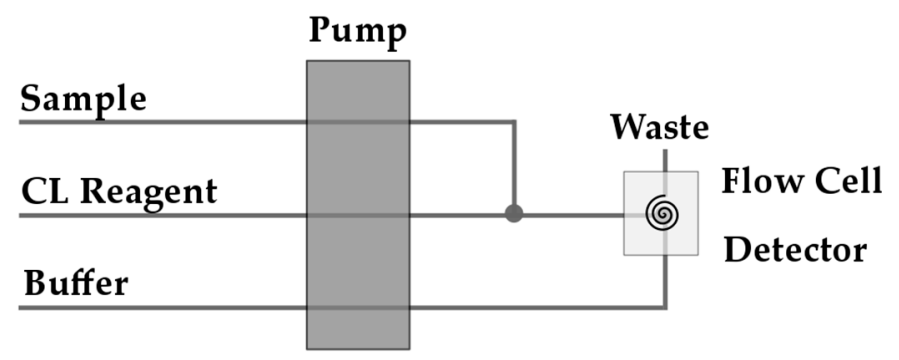

Figure 5. Flow injection analysis (FIA) setup for $\mathrm{H}_{2} \mathrm{O}_{2}$ detection. The sample and the chemiluminescent (CL) reagent are mixed and the $\mathrm{pH}$ is adjusted by the buffer in the flow cell. The signal is detected there (with a photo multiplier tube (PMT)). Depending on the system, a washing solution (diluted $\mathrm{HCl}$ ) can be added to avoid clocking of the system; this is useful especially when working with seawater. With more complicated systems a multivalve for sample injection can be used. For more information see for example King et al. [128].

Overall, advantages of FIA-based $\mathrm{H}_{2} \mathrm{O}_{2}$ detection are that $\mathrm{pH}$ cross-sensitivities can be counterbalanced by adding buffer solutions, the method enables quantification of dynamic change in $\mathrm{H}_{2} \mathrm{O}_{2}$, continuous measurements are possible (even over a long time), and the technique is adjustable to different experimental settings and samples. However, besides cross-sensitivity, analyte and reactant are consumed, there are restrictions due to the sample's volume, and chemiluminescent reactions are 
strongly temperature dependent (making field measurements potentially difficult). Additionally, those relatively large sampling volumes limit spatial or temporal resolution.

\subsection{Redox Systems}

Another technique now gaining a lot of attention is the redox 'sensor' for $\mathrm{H}_{2} \mathrm{O}_{2}$ measurements. Such detection systems have a true sensor-like performance but still need to be 'externally' regenerated, and thus quantify an accumulative $\mathrm{H}_{2} \mathrm{O}_{2}$ concentration over deployment time. One example is the Prussian Blue (PB)-Prussian White (PW) redox pair, where PW is oxidized by $\mathrm{H}_{2} \mathrm{O}_{2}$ to $\mathrm{PB}$ (or $\mathrm{K}_{3} \mathrm{Fe}(\mathrm{CN})_{6}$ [70]) exhibiting a strong shift in optical properties, which can then be regenerated by a reducing agent such as ascorbic acid [69,70]. Koren et al. [69] use a highly photostable luminescent crystal coupled to the $\mathrm{PB} / \mathrm{PW}$ pair, using the inner-filter effect to correlate changes in luminescence to changes in $\mathrm{H}_{2} \mathrm{O}_{2}$ concentration (Figure 6).

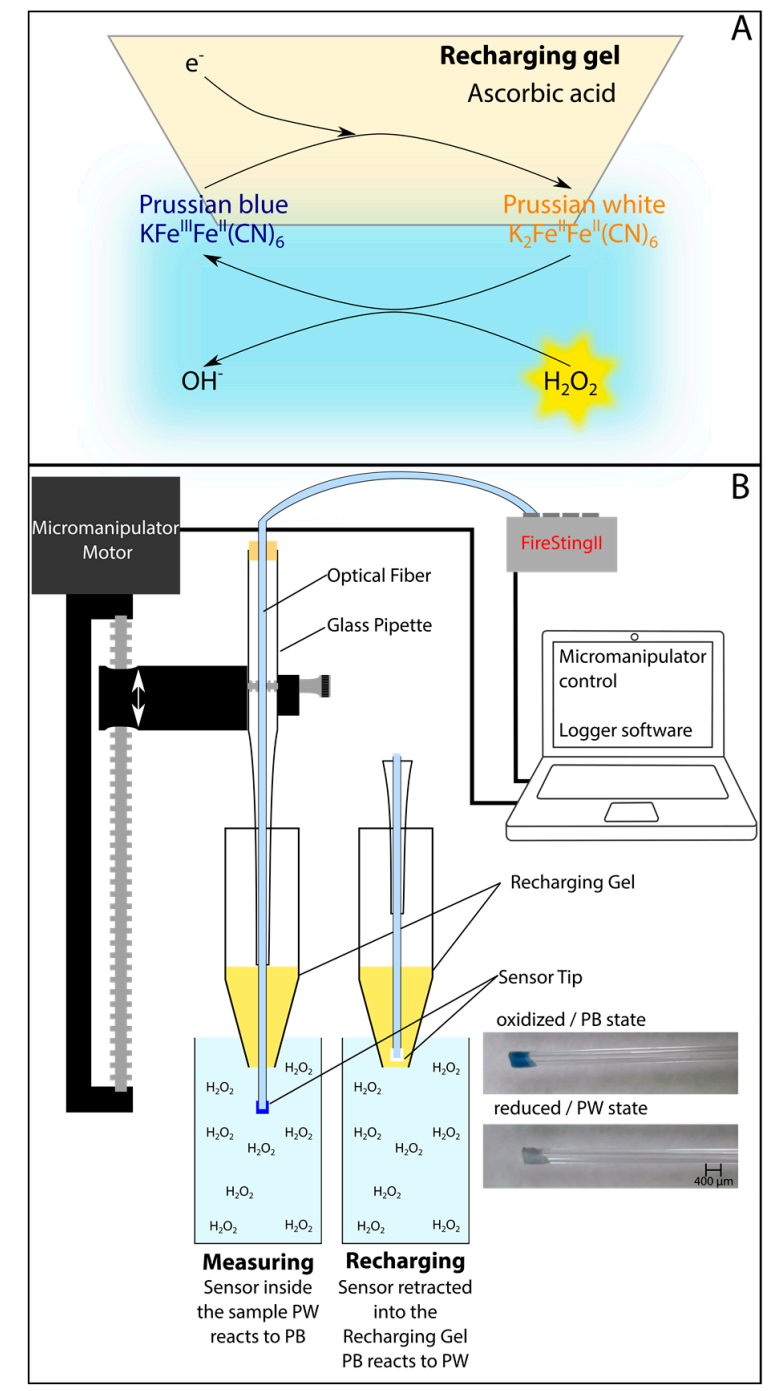

Figure 6. Principle for a fiber-optic $\mathrm{H}_{2} \mathrm{O}_{2}$ detection system. (A) Shows the Prussian Blue (PB)/Prussian White (PW) redox scheme. $\mathrm{PW}$ is oxidized to $\mathrm{PB}$ by $\mathrm{H}_{2} \mathrm{O}_{2}$ in the sample. It can then be regenerated externally by reducing it with e.g., ascorbic acid to PW; (B) PB coated on a fiber tip together with a luminescent crystal, allowing pseudo-continuous measurements with an optical fiber. The fiber can be retracted into the recharging gel to regenerate the tip in between measurements. Reproduced from [69]-Published by The Royal Society of Chemistry. 
However, Koncki et al. [70] observed not only an optical response of $\mathrm{PW}$ to $\mathrm{H}_{2} \mathrm{O}_{2}$, but also to chromate, dichromate, permanganate, chlorine, bromine, iodine, hexacyanoferrate(III), Fe(III), as well as a slow response to $\mathrm{O}_{2}$ resulting in a drifting baseline. Cross-sensitivities to $\mathrm{K}^{+}, \mathrm{Na}^{+}$, and $\mathrm{pH}$ were observed in PB films, and PB can be reduced to $\mathrm{PW}$ by $\mathrm{H}_{2} \mathrm{~S}$, ascorbic acid, and various mercapto-compounds [70]. This last example makes it clear that this system should mainly be chosen to measure $\mathrm{H}_{2} \mathrm{O}_{2}$ in samples which rule out the presence of the above mentioned species as well as large fluctuations in $\mathrm{pH}$, as has also been discussed by Koren et al. [69]. Therefore, these cross-interferences need to be taken into consideration when planning an experiment or choosing an application. The $\mathrm{pH}$ interferences for PB/PW based detection schemes were investigated in detail by Khorami et al. [138].

Other redox systems are based on e.g., a naphtho[1,8-cd]-1,2-dithiole-5-carboxaldehyde functionalized fluorescein, which is (de-)protonated with treatment of either the mild oxidizer $\mathrm{H}_{2} \mathrm{O}_{2}$ or with a mild reductant. However, the authors also state that this redox sensor can be re-oxidized even by air [71]. Another approach relies on the redox probe naphtopyran-benzothiazolium, which reacts with $\mathrm{H}_{2} \mathrm{O}_{2}$ as well as bisulfite [139]. Another system detects $\mathrm{H}_{2} \mathrm{O}_{2}$ as oxidizer and uses $N$-acetyl-L-cysteine as antioxidant together with 2,3,4,5,6-pentafluorodihydrotetramethylrosamine (Redox-Sensor Red). The authors, however, state themselves that the sensor material is readily oxidized by various other species [72].

$\mathrm{Xu}$ et al. [73] published a NIR fluorescent probe that can be oxidized by $\mathrm{H}_{2} \mathrm{O}_{2}$ and is reducible by glutathione. They coupled an ebselen moiety onto a cyanine-based fluorophore, which responded with an increase in fluorescence to $\mathrm{H}_{2} \mathrm{O}_{2}$ and with a decrease to glutathione. The fluorescence signal was shown to be relatively stable $\mathrm{pH}$ 6.5-8.4, but showed a relatively strong response to different thiols. The authors proposed two different reaction mechanisms for the reaction with $\mathrm{H}_{2} \mathrm{O}_{2}$ (resulting in the fluorescent form) and other ROS resulting in a weakly fluorescing dimer.

It can be concluded that the use of redox sensors for $\mathrm{H}_{2} \mathrm{O}_{2}$ detection is restricted to measurements in well characterized or defined environments /media, while they are very difficult to apply in complex biological samples where various oxidizing as well as reducing species might be present, and local $\mathrm{pH}$ changes can occur.

\section{Fully Reversible Optical Chemical Sensors}

Wolfbeis et al. [140] described a reversible $\mathrm{H}_{2} \mathrm{O}_{2}$ sensor system, based on the previously described luminescence increase of fluorescent (tetracycline)europium(III) (EuTc) in the presence of $\mathrm{H}_{2} \mathrm{O}_{2}$ [141] due to coordination, rather than reaction [140]. The reversibility, however, is due to flushing with $\mathrm{H}_{2} \mathrm{O}$ (or faster with thiosulfate) $[44,140]$ in order to resubstitute the coordinated $\mathrm{H}_{2} \mathrm{O}_{2}$ molecules and, thus, needs to be done 'externally'. In addition, the system shows relatively slow response times ( 10 min) and cross-sensitivities to $\mathrm{Cu}^{2+}$ (which quenches strongly), phosphate, and citrate (which increase fluorescence intensities strongly) [140]. Another study concluded that there is no linear correlation between the $\mathrm{H}_{2} \mathrm{O}_{2}$ concentration and the fluorescence intensity increase at the complex transition and concluded that this measuring scheme is of limited value for $\mathrm{H}_{2} \mathrm{O}_{2}$ detection [142].

A different more frequently used technique relies on the well-established optical detection of $\mathrm{O}_{2}$. There are various mechanisms converting $\mathrm{H}_{2} \mathrm{O}_{2}$ in oxygen, which then results in an increase of measured $\mathrm{O}_{2}$. This can be achieved e.g., by covering a planar $\mathrm{O}_{2}$ sensitive layer based on luminescence quenching with a second layer containing an inorganic catalyst (such as $\mathrm{MnO}_{2}$ [143], or finely dispersed Ag-powder), by co-absorbing catalase in silica gel/the same phase as the indicator layer, or alternatively, by adsorption of enzyme and dye on silica gel particles, which are then immobilized in a polymer layer [144] (Figure 7). 
A

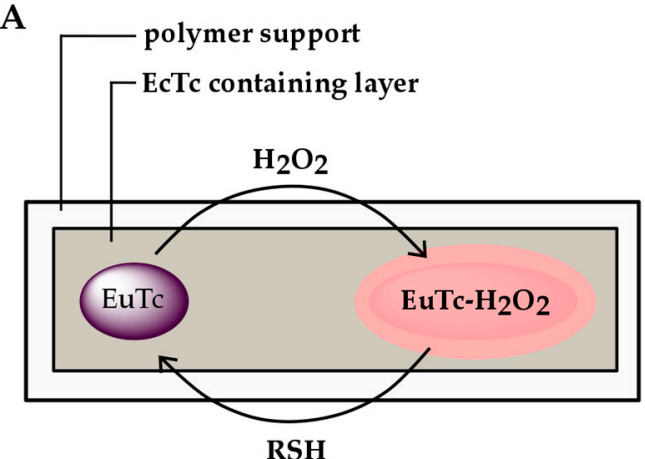

B

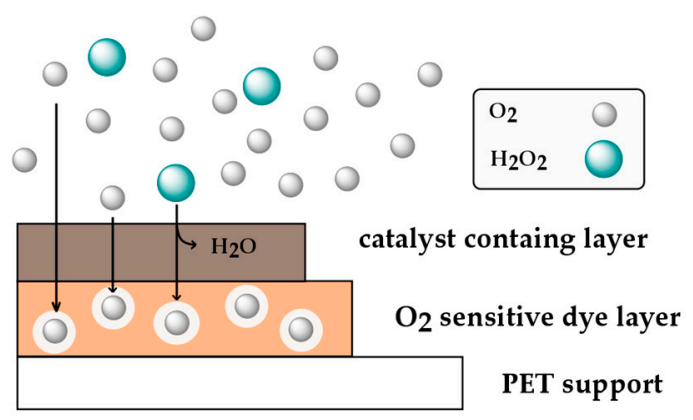

Figure 7. Principle for quasi-reversible luminescence based detection of $\mathrm{H}_{2} \mathrm{O}_{2}$. (A) Reversible $\mathrm{H}_{2} \mathrm{O}_{2}$ sensor, based on the coordination of $\mathrm{H}_{2} \mathrm{O}_{2}$ to EuTc resulting in a strongly fluorescent complex. The reaction can be reversed by adding thiols; (B) Schematic depiction showing indirect $\mathrm{H}_{2} \mathrm{O}_{2}$ sensing via $\mathrm{O}_{2}$ measurements. Hydrogen peroxide (blue) is degraded in the catalyst-containing layer into water and $\mathrm{O}_{2}$; which then is detected via fluorescence quenching (white ring around the $\mathrm{O}_{2}$ ) of an indicator dye, together with background $\mathrm{O}_{2}$ (gray).

This method has one clear advantage against all the other methods described above; the sensing system it relies on is truly reversible. However, background $\mathrm{O}_{2}$ and fluctuations in it have to be taken into consideration and need to be compensated for e.g., by simultaneous, external $\mathrm{O}_{2}$ measurements.

\section{Conclusions}

There is a wide variety of published techniques to determine $\mathrm{H}_{2} \mathrm{O}_{2}$ concentrations. However, there is still a long way to go with regard to realizing a reliable optical $\mathrm{H}_{2} \mathrm{O}_{2}$ sensor for quantitative and continuous measurements (Table 1). No selective, reversible optical sensing principle for direct $\mathrm{H}_{2} \mathrm{O}_{2}$ determination has been reported. A relatively broad selection of $\mathrm{H}_{2} \mathrm{O}_{2}$ probes is available but their use for selective $\mathrm{H}_{2} \mathrm{O}_{2}$ detection is compromised by an array of limitations: They are irreversible; therefore only an increase in concentration can be detected; the probe material is used up; thus the user has to deal with an ever changing system, which usually cannot be calibrated properly (as it is consumed in the meantime-not true for the flow injection systems); the measurement cannot be started at a defined time point-when the probe is in contact with the sample the 'measurement' begins; thus there is often no time for equilibration. Additionally, many probes show a lack of selectivity, which means they react readily (and sometimes even much faster than with $\mathrm{H}_{2} \mathrm{O}_{2}$ ) with another analyte. Another quite problematic issue becomes apparent when looking at the published values of $\mathrm{H}_{2} \mathrm{O}_{2}$ concentration in different samples (summarized in the Supplementary Materials [24,25,110,128,135-137,145-182]).

There is frequently a big variance between the published values and unprecise methods cannot be ruled out as comparative studies are missing. For example, $\mathrm{H}_{2} \mathrm{O}_{2}$ concentrations measured in blood plasma of healthy humans span a wide concentration range of $<0.25 \mu \mathrm{M}[160,161], \sim 2.5 \mu \mathrm{M}$ [163], $\sim 5.85-9.09 \mu \mathrm{M}$ [164], 13-57 $\mu \mathrm{M}$ [162], and $21.3 \mu \mathrm{M}$ [166]. This underscores an urgent need for a robust, reversible and reliable optical $\mathrm{H}_{2} \mathrm{O}_{2}$ sensor system. $\mathrm{H}_{2} \mathrm{O}_{2}$ is a highly important analyte and it will be important for future research to be able to quantify this analyte in real time. We think there is still room for new creative sensing schemes and solutions, but also improvements of current methods are needed. As a start we recommend to carefully study cross-sensitivities and to document them as well as possible. This will increase the reliability of the obtained data. 
Table 1. Advantages, disadvantages and limitations of optical, chemical $\mathrm{H}_{2} \mathrm{O}_{2}$ detection schemes.

\begin{tabular}{|c|c|c|}
\hline Technique & Advantages & Disadvantages/Limitations \\
\hline \multicolumn{3}{|c|}{ Intracellular $\mathrm{H}_{2} \mathrm{O}_{2}$ Measurements } \\
\hline $\begin{array}{l}\text { Oxidative Cleavage-Based } \\
\text { Probes }\end{array}$ & $\begin{array}{l}\text { Easily tunable emission spectrum (by } \\
\text { changing the dye backbone or } \\
\text { substituents), } \\
\text { Accumulative } \mathrm{H}_{2} \mathrm{O}_{2} \text { measurement, } \\
\text { Can show hotspots, } \\
\text { Can be used for comparison of treatments, } \\
\text { Fast response times, } \\
\text { High signal-to-background ratios. }\end{array}$ & $\begin{array}{l}\text { Irreversible } \\
\text { Cross-sensitivities (e.g., other ROS, pH, temperature) } \\
\text { No absolute concentrations, } \\
\text { Cannot be calibrated in situ, } \\
\text { No in situ referencing, } \\
\text { In situ measurements do not start at a defined time point, } \\
\text { Issue of cytotoxicity and chemical perturbation effects. }\end{array}$ \\
\hline Nanomaterials & $\begin{array}{l}\text { Highly and easily tunable properties, } \\
\text { Do not necessarily rely on diffusion into } \\
\text { the cell, } \\
\text { Can be water-soluble or insoluble, } \\
\text { Long fluorescent lifetimes, } \\
\text { High photo-stability. }\end{array}$ & $\begin{array}{l}\text { Irreversible, } \\
\text { Some QDs contain heavy metals (cytotoxicity and } \\
\text { problematic for environment), } \\
\text { Cross-sensitivities to other species, temperature or pH } \\
\text { (dependent on material), } \\
\text { Cannot be calibrated in situ, } \\
\text { In situ measurements do not start at a defined time point. }\end{array}$ \\
\hline \multicolumn{3}{|c|}{ Extracellular $\mathrm{H}_{2} \mathrm{O}_{2}$ Measurements } \\
\hline $\begin{array}{l}\text { Chemiluminescent } \\
\text { Reactions }\end{array}$ & $\begin{array}{l}\text { High signal-to-background ratio, } \\
\text { Spectral properties can be easily adjusted. }\end{array}$ & $\begin{array}{l}\text { Irreversible, } \\
\text { Temperature dependency, } \\
\text { Reaction dependent interferences (e.g., Ag(I), Cu(II), Co(II), } \\
\text { Fe(II), pH, ROS, hydroperoxides ... ). }\end{array}$ \\
\hline Assays & $\begin{array}{l}\text { Well established for biological fluids, } \\
\text { Allows monitoring of } \mathrm{H}_{2} \mathrm{O}_{2} \text { dynamics } \\
\text { over time. }\end{array}$ & $\begin{array}{l}\text { Irreversible, } \\
\text { Cross-sensitivities (e.g., NADH, reduced glutathione, ROS, } \\
\text { pH, phenols ... ), } \\
\text { Low temporal-resolution, } \\
\text { Samples need to be taken prior to measurement. }\end{array}$ \\
\hline Redox Systems & $\begin{array}{l}\text { Can be reversed externally, } \\
\text { Allow pseudo-continuous measurements, } \\
\text { Sensor material is not used up, } \\
\text { Insight into redox processes, } \\
\text { Allow quantitative measurements. }\end{array}$ & $\begin{array}{l}\text { Can react with other oxidizing/reducing species, } \\
\text { Other species can interfere within the system } \\
\text { Possible pH dependencies. }\end{array}$ \\
\hline \multicolumn{3}{|c|}{ Quasi Reversible Optical $\mathrm{H}_{2} \mathrm{O}_{2}$ Sensors } \\
\hline $\begin{array}{l}\text { (tetracycline)europium(III) } \\
\text { (EuTc) }\end{array}$ & $\begin{array}{l}\text { Reversible, } \\
\text { Sensor material is not used up } \\
\text { (coordination of } \mathrm{H}_{2} \mathrm{O}_{2} \text { ) }\end{array}$ & $\begin{array}{l}\text { External source needed to reverse, } \\
\text { Reversible with water or thiosulfate } \\
\text { Slow response time }(\sim 10 \mathrm{~min}), \\
\text { Quenched by } \mathrm{Cu}^{2+}, \\
\text { Interferences from phosphate and citrate. }\end{array}$ \\
\hline $\begin{array}{l}\text { Indirect } \mathrm{H}_{2} \mathrm{O}_{2} \\
\text { Determination via } \mathrm{O}_{2} \\
\text { Measurements }\end{array}$ & $\begin{array}{l}\text { Fully reversible, } \\
\text { Allows continuous monitoring, } \\
\text { Well established chemistry, } \\
\text { Allows quantitative } \mathrm{H}_{2} \mathrm{O}_{2} \text { measurement. }\end{array}$ & $\begin{array}{l}\text { Low signal against a high background, } \\
\text { Fluctuations in } \mathrm{O}_{2} \text { need to be accounted for. }\end{array}$ \\
\hline
\end{tabular}

It is very unlikely that there will be a "universal sensor" developed any time soon which could be used in all media and with all types of samples. More realistically a variety of sensor systems will be developed or optimized for different types of applications. By carefully analyzing the analytical problem at hand (e.g., changes in the $\mathrm{pH}$ of the sample, or the presence of other ROS), suitable sensor solutions can be found and in combination with proper controls, quantification might be possible. Nevertheless, in the long run new approaches will be needed to really advance the field. It will not be enough to attach the same cleavable groups onto different fluorophores, and novel reactions and ways to detect $\mathrm{H}_{2} \mathrm{O}_{2}$ are needed. Cross-sensitivities could be minimized in the future by shielding the 
indicator within a suitable sensor matrix (e.g., within nanoparticles) that blocks or quenches interfering species. Also new sampling methods could be used to increase the temporal and spatial resolution of e.g., intermediate $\mathrm{H}_{2} \mathrm{O}_{2}$ sensing systems. It is safe to say that there is plenty of room for developing new sensing solutions and that any specific and robust system that allows continuous measurements of $\mathrm{H}_{2} \mathrm{O}_{2}$ - down to trace amounts—-will be highly valued within the community. Researchers within different fields aim to understand the role of $\mathrm{H}_{2} \mathrm{O}_{2}$ in a variety of living systems and habitats. Getting in touch with the (potential) users will highlight their particular application demands and boundary conditions, and this will guide sensor developers in the development of suitable tools.

Supplementary Materials: The following are available online at www.mdpi.com/2227-9040/5/4/28/s1, Table S1: Hydrogen peroxide concentrations found in natural waters; Table S2: Hydrogen peroxide concentrations found in the human body; Table S3: Hydrogen peroxide concentrations in other biological samples.

Acknowledgments: This study was supported by a grant from a Sapere-Aude Advanced grant from the Danish Research Council for Independent Research (M.K.), and a grant by the Danish Research Council for Independent Research I Technical and Production Sciences (M.K., K.K. and M.M.).

Author Contributions: M.M., M.K., and K.K. outlined this paper; M.M. wrote the review paper with editorial input from M.K. and K.K. All three authors contributed to the final paper.

Conflicts of Interest: The authors declare no conflict of interest. The founding sponsors had no role in the design of the study; in the collection, analysis, or interpretation of data; in the writing of the manuscript, and in the decision to publish the results.

\section{References}

1. Gough, D.R.; Cotter, T.G. Hydrogen peroxide: A Jekyll and Hyde signalling molecule. Cell Death Dis. 2011, 2, 1-8. [CrossRef] [PubMed]

2. Rhee, S.G. $\mathrm{H}_{2} \mathrm{O}_{2}$, a Necessary Evil for Cell Signaling. Science 2006, 312, 1882-1883. [CrossRef] [PubMed]

3. Zhao, W. Lighting up $\mathrm{H}_{2} \mathrm{O}_{2}$ : The molecule that is a "necessary evil" in the cell. Angew. Chem. Int. Ed. 2009, 48, 3022-3024. [CrossRef] [PubMed]

4. Shah, A.M.; Channon, K.M. Free radicals and redox signalling in cardiovascular disease. Heart 2004, 90, 486-487. [CrossRef] [PubMed]

5. Giorgio, M.; Trinei, M.; Migliaccio, E.; Pelicci, P.G. Hydrogen peroxide: A metabolic by-product or a common mediator of ageing signals? Nat. Rev. Mol. Cell Biol. 2007, 8, 722-728. [CrossRef] [PubMed]

6. Wang, P.; Wang, K.; Chen, D.; Mao, Y.; Gu, Y. A novel colorimetric and near-infrared fluorescent probe for hydrogen peroxide imaging in vitro and in vivo. RSC Adv. 2015, 5, 85957-85963. [CrossRef]

7. Schäferling, M.; Grögel, D.B.M. Luminescent probes for detection and imaging of hydrogen peroxide. Microchim. Acta 2011, 174, 1-18. [CrossRef]

8. Barnham, K.J.; Masters, C.L.; Bush, A.L. Neurodegenerative diseases and oxidative stress. Nat. Rev. Drug Discov. 2004, 3, 205-214. [CrossRef] [PubMed]

9. Tabner, B.J.; El-Agnaf, O.M.A.; Turnbull, S.; German, M.J.; Paleologou, K.E.; Hayashi, Y.; Cooper, L.J.; Fullwood, N.J.; Allsop, D. Hydrogen peroxide is generated during the very early stages of aggregation of the amyloid peptides implicated in Alzheimer disease and familial British dementia. J. Biol. Chem. 2005, 280, 35789-35792. [CrossRef] [PubMed]

10. Yang, J.; Yang, J.; Liang, S.H.; Xu, Y.; Moore, A.; Ran, C. Imaging hydrogen peroxide in Alzheimer's disease via cascade signal amplification. Sci. Rep. 2016, 6, 35613. [CrossRef] [PubMed]

11. Krishnan, C.V.; Garnett, M.; Chu, B. Spatiotemporal Oscillations in Biological Molecules: Hydrogen Peroxide and Parkinson's Disease. Int. J. Electrochem. Sci. 2008, 3, 1364-1385.

12. Dias, V.; Junn, E.; Mouradian, M.M. The Role of Oxidative Stress in Parkinson's Disease. J. Park. Dis. 2013, 3, 461-491. [CrossRef]

13. Lisanti, M.P.; Martinez-Outschoorn, U.E.; Lin, Z.; Pavlides, S.; Whitaker-Menezes, D.; Pestell, R.G.; Howell, A.; Sotgia, F. Hydrogen peroxide fuels aging, inflammation, cancer metabolism and metastasis-The seed and soil also needs "fertilizer". Cell Cycle 2011, 10, 2440-2449. [CrossRef] [PubMed]

14. López-Lázaro, M. Dual role of hydrogen peroxide in cancer: Possible relevance to cancer chemoprevention and therapy. Cancer Lett. 2007, 252, 1-8. [CrossRef] [PubMed] 
15. Ho, L.P.; Faccenda, J.; Innes, J.A.; Greening, A.P. Expired hydrogen peroxide in breath condensate of cystic fibrosis patients. Eur. Respir. J. 1999, 13, 103-106. [CrossRef] [PubMed]

16. Veal, E.A.; Day, A.M.; Morgan, B.A. Hydrogen Peroxide Sensing and Signaling. Mol. Cell 2007, 26, 1-14. [CrossRef] [PubMed]

17. Haskew-Layton, R.E.; Payappilly, J.B.; Smirnova, N.A.; Ma, T.C.; Chan, K.K.; Murphy, T.H.; Guo, H.; Langley, B.; Sultana, R.; Butterfield, D.A.; et al. Controlled enzymatic production of astrocytic hydrogen peroxide protects neurons from oxidative stress via an Nrf2-independent pathway. Proc. Natl. Acad. Sci. USA 2010, 107, 17385-17390. [CrossRef] [PubMed]

18. Winterbourn, C.C. The Biological Chemistry of Hydrogen Peroxide. In Methods in Enzymology; Elsevier Inc.: Philadelphia, PA, USA, 2013; Volume 528, pp. 3-25, ISBN 9780124058811.

19. Halliwell, B.; Clement, M.V.; Long, L.H. Hydrogen peroxide in the human body. FEBS Lett. 2000, 486, 10-13. [CrossRef]

20. Imlay, J.A.; Linn, S. Mutagenesis and Stress Responses Induced in Escherichia coli by Hydrogen Peroxide. J. Bacteriol. 1987, 169, 2967-2976. [CrossRef] [PubMed]

21. Hampton, M.B.; Orrenius, S. Dual regulation of caspase activity by hydrogen peroxide: Implications for apoptosis. FEBS Lett. 1997, 414, 552-556. [CrossRef]

22. Gonza, B.; Demple, B. Homeostatic Regulation of Intracellular Hydrogen Peroxide Concentration in Aerobically Growing Escherichia coli. J. Bacteriol. 1997, 179, 382-388.

23. Downs, C.A.; Fauth, J.E.; Halas, J.C.; Dustan, P.; Bemiss, J.; Woodley, C.M. Oxidative stress and seasonl coral bleaching. Free Radic. Biol. Med. 2002, 33, 533-543. [CrossRef]

24. Febria, C.M.; Lesack, L.F.W.; Gareis, J.A.L.; Bothwell, M.L. Patterns of hydrogen peroxide among lakes of the Mackenzie Delta, western Canadian Arctic. Can. J. Fish. Aquat. Sci. 2006, 63, 2107-2118. [CrossRef]

25. Reimer, H. The Daily Changing Pattern of Hydrogen Peroxide in New Zealand. Environ. Toxicol. Chem. 1996, 15, 652-662.

26. Burns, J.M.; Cooper, W.J.; Ferry, J.L.; King, D.W.; DiMento, B.P.; McNeill, K.; Miller, C.J.; Miller, W.L.; Peake, B.M.; Rusak, S.A.; et al. Methods for reactive oxygen species (ROS) detection in aqueous environments. Aquat. Sci. 2012, 74, 683-734. [CrossRef]

27. Dhawan, V. Reactive Oxygen and Nitrogen Species: Generation of ROS. In Studies on Respiratory Disorders; Ganguly, N., Jindal, S., Biswal, S., Barnes, P., Pawankar, R., Eds.; Humana Press: New York, NY, USA, 2014; pp. 27-47, ISBN 9781493904976.

28. Bent, H.A.; Liebman, J.F. Paradigms and paradoxes: The weak bonds in elemental halogens, peroxides, disulfides, interhalogens, noble gas monohalide cations, and isoelectronic species. Struct. Chem. 2011, 22, 371-372. [CrossRef]

29. Neftel, A.; Jacob, P.; Klockow, D. Long-term record of $\mathrm{H}_{2} \mathrm{O}_{2}$ in polar ice cores. Tellus 1986, 262-270. [CrossRef]

30. Sigg, A.; Neftel, A. Seasonal variations in hydrogen peroxide in polar ice cores. Ann. Glaciol. 1988, 10, 157-162. [CrossRef]

31. Guo, H.; Aleyasin, H.; Dickinson, B.C.; Haskew-layton, R.E.; Ratan, R.R. Recent advances in hydrogen peroxide imaging for biological applications. Cell Biosci. 2014, 4, 1-10. [CrossRef] [PubMed]

32. Winterbourn, C.C. Reconciling the chemistry and biology of reactive oxygen species. Nat. Chem. Biol. 2008, 4, 278-286. [CrossRef] [PubMed]

33. Wang, X.; Wolfbeis, O.S. Optical methods for sensing and imaging oxygen: Materials, spectroscopies and applications. Chem. Soc. Rev. 2014, 43, 3666-3761. [CrossRef] [PubMed]

34. Wolfbeis, O.S.; Resch-Genger, U. Standardization and Quality Assurance in Fluorescence Measurements I; Springer: Berlin/Heidelberg, Germany, 2008; ISBN 9783540752066.

35. Hulanicki, A.; Glab, S.; Ingman, F. Chemical Sensors Definitions and Classifications. Pure Appl. Chem. 1991, 63, 1247-1250. [CrossRef]

36. Wolfbeis, O.S. Probes, Sensors, and Labels: Why is Real Progress Slow? Angew. Chem. Int. Ed. 2013, 52, 9864-9865. [CrossRef] [PubMed]

37. Eror, N.G.; Coppersmith, S.N.; Dean, P.D.; Murray, R.W.; Peercy, P.S.; Rogers, C.A.; Sadoway, D.R.; Thome, J.R.; Wagner, J.W. Expanding the Vision of Sensor Materials; National Academy Press: Washington, DC, USA, 1995; ISBN 0309587433.

38. Li, R.; Liu, X.; Qiu, W.; Zhang, M. In Vivo Monitoring of $\mathrm{H}_{2} \mathrm{O}_{2}$ with Polydopamine and Prussian Blue-coated Microelectrode. Anal. Chem. 2016, 88, 7769-7776. [CrossRef] [PubMed] 
39. Karyakin, A.A.; Gitelmacher, O.V.; Karyakina, E.E. Prussian Blue-Based First-Generation Biosensor. A Sensitive Amperometric Electrode for Glucose. Anal. Chem. 1995, 67, 2419-2423. [CrossRef]

40. Chen, S.; Yuan, R.; Chai, Y.; Hu, F. Electrochemical sensing of hydrogen peroxide using metal nanoparticles: A review. Microchim. Acta 2013, 180, 15-32. [CrossRef]

41. Chen, W.; Cai, S.; Ren, Q.; Wen, W.; Zhao, Y. Recent advances in electrochemical sensing for hydrogen peroxide: A review. Analyst 2012, 137, 49-58. [CrossRef] [PubMed]

42. Calas-Blanchard, C.; Catanante, G.; Noguer, T. Electrochemical Sensor and Biosensor Strategies for ROS/RNS Detection in Biological Systems. Electroanalysis 2014, 26, 1277-1286. [CrossRef]

43. Zhao, Z.; Ou, Q.; Yin, X.; Liu, J. Nanomaterial-Based Electrochemical Hydrogen Peroxide Biosensor. Int. J. Biosens. Bioelectron. 2017, 2, 25-28. [CrossRef]

44. Burmistrova, N.A.; Kolontaeva, O.A.; Duerkop, A. New Nanomaterials and Luminescent Optical Sensors for Detection of Hydrogen Peroxide. Chemosensors 2015, 3, 253-273. [CrossRef]

45. Żamojć, K.; Zdrowowicz, M.; Jacewicz, D.; Chmurzyński, L. Fluorescent Probes Used for Detection of Hydrogen Peroxide under Biological Conditions. Crit. Rev. Anal. Chem. 2016, 46, 171-200. [CrossRef] [PubMed]

46. Soh, N. Recent advances in fluorescent probes for the detection of reactive oxygen species. Anal. Bioanal. Chem. 2006, 386, 532-543. [CrossRef] [PubMed]

47. Lee, Y.-E.K.; Kopelman, R. Nanoparticle PEBBLE Sensors in Live Cells. In Methods in Enzymology; Elsevier Inc.: Philadelphia, PA, USA, 2012; Volume 504, pp. 419-470, ISBN 9780123918574.

48. Winterbourn, C.C. The challenges of using fluorescent probes to detect and quantify specific reactive oxygen species in living cells. Biochim. Biophys. Acta 2014, 1840, 730-738. [CrossRef] [PubMed]

49. Chan, J.; Dodani, S.C.; Chang, C.J. Reaction-based small molecule fluorescent probes for chemoselective bioimaging. Nat. Chem. 2012, 4, 973-984. [CrossRef] [PubMed]

50. Miller, E.W.; Albers, A.E.; Pralle, A.; Isacoff, E.Y.; Chang, C.J. Boronate-Based Fluorescent Probes for Imaging Cellular Hydrogen Peroxide. J. Am. Chem. Soc. 2005, 127, 16652-16659. [CrossRef] [PubMed]

51. Daniel, K.B.; Agrawal, A.; Manchester, M.; Cohen, S.M. Readily Accessible Fluorescent Probes for Sensitive Biological Imaging of Hydrogen Peroxide. Chembiochem 2013, 14, 593-598. [CrossRef] [PubMed]

52. Lavis, L.D.; Rutkoski, T.J.; Raines, R.T. Tuning the pKa of Fluorescein to Optimize Binding Assays. Anal. Chem. 2007, 79, 6775-6782. [CrossRef] [PubMed]

53. Bueno, C.; Villegas, M.L.; Bertolotti, S.G.; Previtali, C.M.; Neumann, M.G.; Encinas, M.V. The Excited-State Interaction of Resazurin and Resorufin with Amines in Aqueous Solutions. Photophysics and Photochemical Reaction. Photochem. Photobiol. 2002, 76, 385-390. [CrossRef]

54. Song, D.; Lim, M.; Cho, S.; Park, S.-J.; Cho, J.; Kang, D.; Rhee, S.G.; You, Y.; Nam, W. A fluorescence turn-on $\mathrm{H}_{2} \mathrm{O}_{2}$ probe exhibits lysosome-localized fluorescence signals. Chem. Commun. 2012, 48, 5449-5451. [CrossRef] [PubMed]

55. Rhee, S.G.; Chang, T.-S.; Jeong, W.; Kang, D. Methods for Detection and Measurement of Hydrogen Peroxide Inside and Outside of Cells. Mol. Cells 2010, 29, 539-549. [CrossRef] [PubMed]

56. Lin, V.S.; Dickinson, B.C.; Chang, C.J. Boronate-based fluorescent probes: Imaging hydrogen peroxide in living systems. Methods Enzymol. 2013, 526, 19-43. [CrossRef] [PubMed]

57. Dickinson, B.C.; Huynh, C.; Chang, C.J. A palette of fluorescent probes with varying emission colors for imaging hydrogen peroxide signaling in living cells. J. Am. Chem. Soc. 2010, 132, 5906-5915. [CrossRef] [PubMed]

58. Miller, E.W.; Tulyathan, O.; Isacoff, E.Y.; Chang, C.J. Molecular imaging of hydrogen peroxide produced for cell signaling. Nat. Chem. Biol. 2007, 3, 263-268. [CrossRef] [PubMed]

59. Sikora, A.; Zielonka, J.; Lopez, M.; Joseph, J.; Kalyanaraman, B. Direct oxidation of boronates by peroxynitrite: Mechanism and implications in fluorescence imaging of peroxynitrite. Free Radic. Biol. Med. 2009, 47, 1401-1407. [CrossRef] [PubMed]

60. Labutti, J.N.; Gates, K.S. Biologically Relevant Chemical Properties of Peroxymonophosphate $\left(=\mathrm{O}_{3} \mathrm{POOH}\right)$. Bioorg. Med. Chem. Lett. 2009, 19, 218-221. [CrossRef] [PubMed]

61. Zielonka, J.; Sikora, A.; Hardy, M.; Joseph, J.; Dranka, B.P.; Kalyanaraman, B. Boronate probes as diagnostic tools for real time monitoring of peroxynitrite and hydroperoxides. Chem. Res. Toxicol. 2012, 25, 1793-1799. [CrossRef] [PubMed] 
62. Maeda, H.; Fukuyasu, Y.; Yoshida, S.; Fukuda, M.; Saeki, K.; Matsuno, H.; Yamauchi, Y.; Yoshida, K.; Hirata, K.; Miyamoto, K. Fluorescent Probes for Hydrogen Peroxide Based on a Non-Oxidative Mechanism. Angew. Chem. 2004, 43, 2389-2391. [CrossRef] [PubMed]

63. Xu, K.; Tang, B.; Huang, H.; Yang, G.; Chen, Z.; An, L. Strong red fluorescent probes suitable for detecting hydrogen peroxide generated by mice peritoneal macrophages. Chem. Commun. 2005, 5974-5976. [CrossRef] [PubMed]

64. Mohr, G.J. New chromogenic and fluorogenic reagents and sensors for neutral and ionic analytes based on covalent bond formation-A review of recent developments. Anal. Bioanal. Chem. 2006, 386, 1201-1214. [CrossRef] [PubMed]

65. Xu, K.; Liu, F.; Wang, H.; Wang, S.; Wang, L.; Tang, B. Sulfonate-based fluorescent probes for imaging hydrogen peroxide in living cells. Sci. China Ser. B Chem. 2009, 52, 734-740. [CrossRef]

66. Abo, M.; Urano, Y.; Hanaoka, K.; Terai, T.; Komatsu, T.; Nagano, T. Development of a Highly Sensitive Fluorescence Probe for Hydrogen Peroxide. J. Am. Chem. Soc. 2011, 133, 10629-10637. [CrossRef] [PubMed]

67. Kalyanaraman, B.; Darley-usmar, V.; Davies, K.J.A.; Dennery, P.A.; Jay, H.; Grisham, M.B.; Mann, G.E.; Moore, K.; Roberts, L.J.; Ischiropoulos, H. Measuring reactive oxygen and nitrogen species with fluorescent probes: Challenges and limitations. Free Radic. Biol. Med. 2012, 52, 1-6. [CrossRef] [PubMed]

68. LeBel, C.P.; Ischiropoulos, H.; Bondy, S.C. Evaluation of the Probe $2^{\prime}, 7^{\prime}$-Dichlorofluorescein as an Indicator of Reactive Oxygen Species Formation and Oxidative Stress. Chem. Res. Toxicol. 1992, 25, 227-231. [CrossRef]

69. Koren, K.; Jensen, P.Ø.; Kühl, M. Development of a rechargeable optical hydrogen peroxide sensor-Sensor design and biological application. Analyst 2016, 141, 4332-4339. [CrossRef] [PubMed]

70. Koncki, R.; Lenarczuk, T.; Głab, S. Optical sensing schemes for Prussian Blue/Prussian White film system. Anal. Chim. Acta 2000, 424, 27-35. [CrossRef]

71. Miller, E.W.; Bian, S.X.; Chang, C.J. A Fluorescent Sensor for Imaging Reversible Redox Cycles in Living Cells. J. Am. Chem. Soc. 2007, 129, 3458-3459. [CrossRef] [PubMed]

72. Chen, C.-S.; Gee, K.R. Redox-Dependent Trafficking of 2,3,4,5,6- Pentafluoreodihydrotetramethylrosamine, a Novel Fluorogenic Indicator of Cellular Oxidative Activity. Free Radic. Biol. Med. 2000, 28, 1266-1278. [CrossRef]

73. Xu, K.; Qiang, M.; Gao, W.; Su, R.; Li, N.; Gao, Y.; Xie, Y.; Kong, F.; Tang, B. A near-infrared reversible fluorescent probe for real-time imaging of redox status changes in vivo. Chem. Sci. 2013, 4, 1079-1086. [CrossRef]

74. Horikoshi, S.; Serpone, N. Introduction to Nanoparticles. In Microwaves in Nanoparticle Synthesis: Fundamentals and Applications Microwaves in Nanoparticle Synthesis: Fundamentals and Applications; Wiley-VCH Verlag GmbH \& Co. KGaA: Berlin, Germany, 2013; pp. 1-24.

75. Chen, Y.; Xianyu, Y.; Jiang, X. Surface Modification of Gold Nanoparticles with Small Molecules for Biochemical Analysis. Acc. Chem. Res. 2017, 50, 310-319. [CrossRef] [PubMed]

76. Oliveira, E.; Santos, H.M.; Garcia-Pardo, J.; Diniz, M.; Lorenzo, J.; Rodríguez-González, B.; Capelo, J.L.; Lodeiro, C. Synthesis of functionalized fluorescent silver nanoparticles and their toxicological effect in aquatic environments (Goldfish) and HEPG2 cells. Front. Chem. 2013, 1, 1-11. [CrossRef] [PubMed]

77. Tagad, C.K.; Kim, H.U.; Aiyer, K.; More, P.; Kim, T.; Hyun Moh, S.; Kulkarni, A.; Sabharwal, S.G. A sensitive hydrogen peroxide optical sensor based on polysaccharide stabilized silver nanoparticles. RCS Adv. 2013, 3, 22940-22943. [CrossRef]

78. Ajitha, B.; Reddy, Y.A.K.; Reddy, P.S.; Jeon, H.-J.; Ahn, C.W. Role of capping agents in controlling silver nanoparticles size, antibacterial activity and potential application as optical hydrogen peroxide sensor. RSC Adv. 2016, 6, 36171-36179. [CrossRef]

79. Peng, C.; Liu, C.; Xie, Z. Preparation of a fluorescent silver nanoprism-dye complex for detection of hydrogen peroxide in milk. Anal. Methods 2015, 7, 9749-9752. [CrossRef]

80. Liu, C.; Ding, Y.; Li, Q.; Lin, Y. Photochemical synthesis of glutathione-stabilized silver nanoclusters for fluorometric determination of hydrogen peroxide. Microchim. Acta 2017, 184, 2497-2503. [CrossRef]

81. Yuan, Z.; Hu, C.-C.; Chang, H.-T.; Lu, C. Gold nanoparticles as sensitive optical probes. Analyst 2016, 141, 1611-1626. [CrossRef] [PubMed]

82. Shiang, Y.-C.; Huang, C.-C.; Chang, H.-T. Gold nanodot-based luminescent sensor for the detection of hydrogen peroxide and glucose. Chem. Commun. 2009, 3437-3439. [CrossRef] [PubMed] 
83. Molaabasi, F.; Hosseinkhani, S.; Moosavi-Movahedi, A.A.; Shamsipur, M. Hydrogen peroxide sensitive hemoglobin-capped gold nanoclusters as a fluorescence enhancing sensor for the label-free detection of glucose. RSC Adv. 2015, 5, 33123-33135. [CrossRef]

84. Li, Z.; Zhang, H.; Shen, J. Preparation of Stable Luminescent Poly(methyl methacrylate)-Europium Complex Nanospheres and Application in the Detection of Hydrogen Peroxide with the Biocatalytic Growth of Gold Nanoparticles. J. Appl. Polym. Sci. 2013, 845-850. [CrossRef]

85. Chang, H.C.; Ho, J.A.A. Gold Nanocluster-Assisted Fluorescent Detection for Hydrogen Peroxide and Cholesterol Based on the Inner Filter Effect of Gold Nanoparticles. Anal. Chem. 2015, 87, 10362-10367. [CrossRef] [PubMed]

86. Cui, H.; Zhang, Z.-F.; Shi, M.-J.; Xu, Y.; Wu, Y.-L. Light Emission of Gold Nanoparticles Induced by the Reaction of Bis(2,4,6-trichlorophenyl) Oxalate and Hydrogen Peroxide. Anal. Chem. 2005, 77, 6402-6406. [CrossRef] [PubMed]

87. Adegoke, O.; Khene, S.; Nyokong, T. Fluorescence "Switch on" of Conjugates of CdTe @ ZnS Quantum Dots with Al, Ni and Zn Tetraamino-Phthalocyanines by Hydrogen Peroxide: Characterization and Applications as Luminescent Nanosensors. J. Fluoresc. 2013, 23, 963-974. [CrossRef] [PubMed]

88. Li, Y.; Li, B.; Zhang, J. $\mathrm{H}_{2} \mathrm{O}_{2}$ - and $\mathrm{pH}$-sensitive CdTe quantum dots as fluorescence probes for the detection of glucose. J. Biol. Chem. Lumin. 2013, 28, 667-672. [CrossRef] [PubMed]

89. Rivero, P.J.; Ibañez, E.; Goicoechea, J.; Urrutia, A.; Matias, I.R.; Arregui, F.J. A self-referenced optical colorimetric sensor based on silver and gold nanoparticles for quantitative determination of hydrogen peroxide. Sens. Actuators B Chem. 2017, 251, 624-631. [CrossRef]

90. Garg, S.; Rong, H.; Miller, C.J.; Waite, T.D. Oxidative Dissolution of Silver Nanoparticles by Chlorine: Implications to Silver Nanoparticle Fate and Toxicity. Environ. Sci. Technol. 2016, 50, 3890-3896. [CrossRef] [PubMed]

91. Lim, S.Y.; Kim, J.H.; Lee, J.S.; Ahn, J.; Kim, M.-G.; Park, C.B. Multi-layered stacks of fluorescent dye-doped silica nanoparticles decorated by gold nanoparticles for solid-phase optical biosensing. J. Mater. Chem. 2011, 21, 17623-17626. [CrossRef]

92. Li, Z.; Guo, S.; Yuan, Z.; Lu, C. Carbon quantum dot-gold nanocluster nanosatellite for ratiometric fluorescence probe and imaging for hydrogen peroxide in living cells. Sens. Actuators B Chem. 2017, 241, 821-827. [CrossRef]

93. Chu, C.-S.; Hsieh, M.-W.; Su, Z.-R. Hydrogen peroxide sensing based on carbon quantum dots. MATEC Web Conf. ICFST 2016, 59, 1-4. [CrossRef]

94. Gan, Z.; Gui, Q.; Shan, Y.; Pan, P.; Zhang, N.; Zhang, L. Photoluminescence of $\mathrm{MoS}_{2}$ quantum dots quenched by hydrogen peroxide: A fluorescent sensor for hydrogen peroxide. J. Appl. Phys. 2016, 120, 104503. [CrossRef]

95. Chon, C.H.; Li, D. Quantum Dot. In Encyclopedia of Microfluidics and Nanofluidics; Li, D., Ed.; Springer: Berlin, Germany, 2008; pp. 1767-1769, ISBN 978-0-387-32468-5.

96. Barroso, M.M. Quantum Dots in Cell Biology. J. Histochem. Cytochem. 2011, 59, 237-251. [CrossRef] [PubMed]

97. Kim, G.; Lee, Y.-E.K.; Xu, H.; Philbert, M.A.; Kopelman, R. Nanoencapsulation Method for High Selectivity Sensing of Hydrogen Peroxide inside Live Cells. Lett. Anal. Chem. 2010, 82, 2165-2169. [CrossRef] [PubMed]

98. Lee, D.; Khaja, S.; Velasquez-castano, J.C.; Dasari, M.; Sun, C.; Petros, J.; Taylor, W.R.; Murthy, N. In vivo imaging of hydrogen peroxide with chemiluminescent nanoparticles. Nat. Mater. 2007, 6, 765-769. [CrossRef] [PubMed]

99. Lee, I.; Hwang, O.; Yoo, D.; Khang, G.; Lee, D. Detection of Hydrogen Peroxide in vitro and in vivo Using Peroxalate Chemiluminescent Micelles. Bull. Korean Chem. Soc. 2011, 32, 2187-2192. [CrossRef]

100. Banquy, X.; Suarez, F.; Argaw, A.; Rabanel, J.; Grutter, P.; Giasson, S. Effect of mechanical properties of hydrogel nanoparticles on macrophage cell uptake. RCS Soft Matter 2009, 5, 3984-3991. [CrossRef]

101. Barata, A.G.; Dick, T.P. In Vivo Imaging of $\mathrm{H}_{2} \mathrm{O}_{2}$ Production in Drosophila. In Methods in Enzymology; Elsevier Inc.: Berlin, Germany, 2013; Volume 526, pp. 61-82, ISBN 9780124058835.

102. Mishina, N.M.; Markvicheva, K.N.; Bilan, D.S.; Matlashov, M.E.; Shirmanova, M.V.; Liebl, D.; Schultz, C.; Lukyanov, S.; Belousov, V.V. Visualization of Intracellular Hydrogen Peroxide with HyPer, a Genetically Encoded Fluorescent Probe. In Methods in Enzymology; Elsevier Inc.: Berlin, Germany, 2013; Volume 526, pp. 45-59, ISBN 9780124058835. 
103. Belousov, V.V.; Fradkov, A.F.; Lukyanov, K.A.; Staroverov, D.B.; Shakhbazov, K.S.; Terskikh, A.V.; Lukyanov, S. Genetically encoded fluorescent indicator for intracellular hydrogen peroxide. Nat. Methods 2006, 3, 281-286. [CrossRef] [PubMed]

104. Ermakova, Y.G.; Bilan, D.S.; Matlashov, M.E.; Mishina, N.M.; Markvicheva, K.N.; Subach, O.M.; Subach, F.V.; Bogeski, I.; Hoth, M.; Enikolopov, G.; et al. Red fluorescent genetically encoded indicator for intracellular hydrogen peroxide. Nat. Commun. 2014, 5, 1-9. [CrossRef] [PubMed]

105. Zhu, H.; Jia, Z.; Trush, M.A.; Li, Y.R. A Highly Sensitive Chemiluminometric Assay for Real-Time Detection of Biological Hydrogen Peroxide Formation. React. Oxyg. Species 2016, 1, 216-227. [CrossRef]

106. Bienert, G.P.; Schjoerring, J.K.; Jahn, T.P. Membrane transport of hydrogen peroxide. Biochim. Biophys. Acta 2006, 1758, 994-1003. [CrossRef] [PubMed]

107. Griffin, G.D.; Stratis-Cullum, D.N. Biosensors. In Encyclopedia of Microbiology (Third Edition); Elsevier Inc.: Berlin, Germany, 2009; pp. 88-103.

108. Chandross, E.A. A New Chemiluminescent System. Tetrahedron Lett. 1963, 761-765.

109. Kuntzleman, T.S.; Rohrer, K.; Schultz, E. The Chemistry of Lightsticks: Demonstrations To Illustrate Chemical Processes. J. Chem. Educ. 2012, 89, 910-916. [CrossRef]

110. Jacob, P.; Tavares, T.M.; Rocha, V.C.; Klockow, D. Atmospheric $\mathrm{H}_{2} \mathrm{O}_{2}$ field measurements in a tropical environment: Bahia, Brazil. Atmos. Environ. 1990, 24A, 377-382. [CrossRef]

111. Malehorn, C.L.; Riehlt, T.E.; Hinze, W.L. Improved Determination of Hydrogen Peroxide or Lucigenin by Measurement of lucigenin Chemiluminescence in Organised Assemblies. Analyst 1986, 111, 941-947. [CrossRef]

112. Li, Y.; Zhu, H.; Kuppusamy, P.; Roubaud, V.; Zweier, J.L.; Trush, M.A. Validation of Lucigenin (Bis- $N$-methylacridinium) as a Chemilumigenic Probe for Detecting Superoxide Anion Radical Production by Enzymatic and Cellular Systems. J. Biol. Chem. 1998, 273, 2015-2023. [CrossRef] [PubMed]

113. Ma, Q.; Ma, H.; Wang, Z.; Su, M.; Xiao, H.; Liang, S. Synthesis of a novel chemiluminescent reagent for the determination of hydrogen peroxide in snow waters. Talanta 2001, 53, 983-990. [CrossRef]

114. Mátai, A.; Hideg, E. A comparison of colorimetric assays detecting hydrogen peroxide in leaf extracts. Anal. Methods 2017, 9, 2357-2360. [CrossRef]

115. Hong, J.; Maguhn, J.; Freitag, D.; Kettrup, A. Determination of $\mathrm{H}_{2} \mathrm{O}_{2}$ and organic peroxides by high-performance liquid chromatography with post-column UV irradiation, derivatization and fluorescence detection. Fresenius J. Anal. Chem. 1998, 361, 124-128. [CrossRef]

116. Zaitsu, K.; Ohkura, Y. New Fluorogenic Substrates for Horseradish Peroxidase: Rapid and Sensitive Assays for Hydrogen Peroxide and the Peroxidase. Anal. Biochem. 1980, 109, 109-113. [CrossRef]

117. Perschke, H.; Broda, E. Determination of Very Small Amounts of Hydrogen Peroxide. Nature 1961, 190, 257-258. [CrossRef]

118. Andreae, W.A. A Sensitive Method for the Estimation of Hydrogen Peroxide in Biological Materials. Nature 1955, 175, 859-860. [CrossRef] [PubMed]

119. Guilbault, G.G.; Brignac, P.J.; Juneau, M. New Substrates for the Fluorometric Determination of Oxidative Enzymes. Anal. Chem. 1969, 40, 1256-1263. [CrossRef]

120. Puch, W.; Cooper, P.H.; Baggiolini, M. Assay of $\mathrm{H}_{2} \mathrm{O}_{2}$ Production by Macrophages and Neutrophils with Homovanillic Acid and Horse-Radish Peroxidase. J. Immunol. Methods 1983, 63, 347-357.

121. Zhou, M.; Diwu, Z.; Panchuk-Voloshina, N.; Haugland, R.P. A Stable Nonfluorescent Derivative of Resorufin for the Fluorometric Determination of Trace Hydrogen Peroxide: Applications in Detecting the Activity of Phagocyte NADPH Oxidase and Other Oxidases. Anal. Biochem. 1997, 253, 162-168. [CrossRef] [PubMed]

122. Mohanty, J.G.; Jaffe, J.S.; Schulman, E.S.; Raible, D.G. A highly sensitive fluorescent micro-assay of $\mathrm{H}_{2} \mathrm{O}_{2}$ release from activated human leukocytes using a dihydroxyphenoxazine derivative. J. Immunol. Methods 1997, 202, 133-141. [CrossRef]

123. Votyakova, T.V.; Reynolds, I.J. Detection of hydrogen peroxide with Amplex Red: Interference by NADH and reduced glutathione auto-oxidation. Arch. Biochem. Biophys. 2004, 431, 138-144. [CrossRef] [PubMed]

124. Debski, D.; Smulik, R.; Zielonka, J.; Michałowski, B.; Jakubowska, M.; Debowska, K.; Adamus, J.; Marcinek, A.; Kalyanaraman, B.; Sikora, A. Mechanism of oxidative conversion of Amplex ${ }^{\circledR}$ Red to resorufin: Pulse radiolysis and enzymatic studies. Free Radic. Biol. Med. 2016, 95, 323-332. [CrossRef] [PubMed] 
125. Miwa, S.; Treumann, A.; Bell, A.; Vistoli, G.; Nelson, G.; Hay, S.; Von Zglinicki, T. Carboxylesterase converts Amplex red to resorufin: Implications for mitochondrial $\mathrm{H}_{2} \mathrm{O}_{2}$ release assays. Free Radic. Biol. Med. 2016, 90, 173-183. [CrossRef] [PubMed]

126. Edman, L.; Rigler, R. Memory landscapes of single-enzyme molecules. Proc. Natl. Acad. Sci. USA 2000, 97, 8266-8271. [CrossRef] [PubMed]

127. Cooper, W.J.; Moegling, J.K.; Kieber, R.J.; Kiddle, J.J. A chemiluminescence method for the analysis of $\mathrm{H}_{2} \mathrm{O}_{2}$ in natural waters. Mar. Chem. 2000, 70, 191-200. [CrossRef]

128. King, D.W.; Cooper, W.J.; Rusak, S.A.; Peake, B.M.; Kiddle, J.J.; Sullivan, D.W.O.; Melamed, M.L.; Morgan, C.R.; Theberge, S.M. Flow Injection Analysis of $\mathrm{H}_{2} \mathrm{O}_{2}$ in Natural Waters Using Acridinium Ester Chemiluminescence: Method Development and Optimization Using a Kinetic Model. Anal. Chem. 2007, 79, 4169-4176. [CrossRef] [PubMed]

129. Miller, G.W.; Morgan, C.A.; Kieber, D.J.; King, D.W.; Snow, J.A.; Heikes, B.G.; Mopper, K.; Kiddle, J.J. Hydrogen peroxide method intercomparison study in seawater. Mar. Chem. 2005, 97, 4-13. [CrossRef]

130. Morris, J.J.; Johnson, Z.I.; Wilhelm, S.W.; Zinser, E.R. Diel regulation of hydrogen peroxide defenses by open ocean microbial communities. J. Plankton Res. 2016, 38, 1103-1114. [CrossRef]

131. Schneider, R.J.; Roe, K.L.; Hansel, C.M.; Voelker, B.M. Species-Level Variability in Extracellular Production Rates of Reactive Oxygen Species by Diatoms. Front. Chem. 2016, 4, 1-13. [CrossRef] [PubMed]

132. Yuan, J.; Shiller, A.M. Determination of Subnanomolar Levels of Hydrogen Peroxide in Seawater by Reagent-Injection Chemiluminescence Detection. Anal. Chem. 1999, 71, 1975-1980. [CrossRef]

133. Sullivan, D.W.O.; Hanson, A.K.; Kester, D.R. Stopped flow luminol chemiluminescence determination of Fe(II) and reducible iron in seawater at subnanomolar levels. Mar. Chem. 1995, 49, 65-77. [CrossRef]

134. Price, D.; Mantoura, R.F.C.; Worsfold, P.J. Shipboard determination of hydrogen peroxide in the western Mediterranean sea using flow injection with chemiluminescence detection. Anal. Chim. Acta 1998, 371, 205-215. [CrossRef]

135. Hopwood, M.J.; Rapp, I.; Schlosser, C.; Achterberg, E.P. Hydrogen peroxide in deep waters from the Mediterranean Sea, South Atlantic and South Pacific Oceans. Sci. Rep. 2017, 7, 43436. [CrossRef] [PubMed]

136. Tüğsüz, T.; Gök, E.; Ateş, S. Determination of $\mathrm{H}_{2} \mathrm{O}_{2}$ Content of Various Water Samples Using a Chemiluminescence Technique. Turkish J. Chem. 2003, 27, 41-47.

137. Gonçalves, C.; dos Santos, M.A.; Fornaro, A.; Pedrotti, J.J. Hydrogen Peroxide in the Rainwater of Sao Paulo Megacity: Measurements and Controlling Factors. J. Braz. Chem. Soc. 2010, 21, 331-339. [CrossRef]

138. Akbari Khorami, H.; Wild, P.; Brolo, A.G.; Djilali, N. pH-Dependent response of a hydrogen peroxide sensing probe. Sens. Actuators B Chem. 2016, 237, 113-119. [CrossRef]

139. Zhang, W.; Liu, T.; Huo, F.; Ning, P.; Meng, X.; Yin, C. Reversible Ratiometric Fluorescent Probe for Sensing Bisulfate $/ \mathrm{H}_{2} \mathrm{O}_{2}$ and Its Application in Zebrafish. Anal. Chem. 2017, 89, 8079-8083. [CrossRef] [PubMed]

140. Wolfbeis, O.S.; Schäferling, M.; Dürkop, A. Reversible Optical Sensor Membrane for Hydrogen Peroxide Using an Immobilized Fluorescent Probe, and its Application to a Glucose Biosensor. Microchim. Acta 2003, 143, 221-227. [CrossRef]

141. Rakicioglu, Y.; Perrin, J.H.; Schulman, S.G. Increased luminescence of the tetracycline-europium(III) system following oxidation by hydrogen peroxide. J. Pharm. Biomed. Anal. 1999, 20, 397-399. [CrossRef]

142. Dehaen, G.; Absillis, G.; Driesen, K.; Binnemans, K.; Parac-Vogt, T.N. (Tetracycline) europium(III) Complex as Luminescent Probe for Hydrogen Peroxide Detection. Helv. Chim. Acta 2009, 92, 2387-2397. [CrossRef]

143. Voraberger, H.S.; Trettnak, W.; Ribitsch, V. Optochemical hydrogen peroxide sensor based on oxygen detection. Sens. Actuators B 2003, 90, 324-331. [CrossRef]

144. Posch, H.E.; Wolfbeis, O.S. Optical Sensor for Hydrogen Peroxide. Mikrochim. Acta 1989, 1, 41-50. [CrossRef]

145. Rusak, S.A.; Richard, L.E.; Peake, B.M.; Cooper, W.J. Steady state hydrogen peroxide concentrations across the Subtropical Convergence east of New Zealand. In Proceedings of the ASLO 2007 Aquatic Sciences Meeting, Santa Fe, NM, USA, 4-9 February 2005; pp. 3-4.

146. Yuan, J.; Shiller, A.M. Distribution of hydrogen peroxide in the northwest Pacific Ocean. Geochem. Geophys. Geosyst. 2005, 6, 1-13. [CrossRef]

147. Fujiwara, K.; Ushiroda, T.; Takeda, K.; Kumamoto, Y.-I.; Tsubota, H. Diurnal and seasonal dirstribution of hydrogen peroxide in seawater of the Seto Inland Sea. Geochem. J. 1993, 27, 103-115. [CrossRef]

148. Zika, R.; Saltzman, E.; Chameides, W.L.; Davis, D.D. $\mathrm{H}_{2} \mathrm{O}_{2}$ Levels in Rainwater Collected in South Florida and the Bahama Islands. J. Geophys. Res. 1982, 87, 5015-5017. [CrossRef] 
149. Kelly, T.J.; Daum, P.H.; Schwartz, S.E. Measurements of Peroxides in Cloudwater and Rain. J. Geophys. Res. 1985, 90, 7861-7871. [CrossRef]

150. Jacob, P.; Klockow, D. Measurements of hydrogen peroxide in Antarctic ambient air, snow and firn cores. Anal. Chem. 1993, 429-434. [CrossRef]

151. Cooper, W.J.; Zika, R.; Petasne, R.G.; Plane, J.M.C. Photochemical Formation of $\mathrm{H}_{2} \mathrm{O}_{2}$ in Natural Waters Exposed to Sunlight. Environ. Sci. Technol. 1988, 22, 1156-1160. [CrossRef] [PubMed]

152. Meslé, M.M.; Beam, J.P.; Jay, Z.J.; Bodle, B.; Bogenschutz, E.; Inskeep, W.P. Hydrogen Peroxide Cycling in High-Temperature Acidic Geothermal Springs and Potential Implications for Oxidative Stress Response. Front. Mar. Sci. 2017, 4, 1-12. [CrossRef]

153. Ryan, C.S.; Kleinberg, I. Bacteria in Human Mouths Involved in the Production and Utilization of Hydrogen Peroxide. Arch. Oral Biol. 1995, 40, 753-763. [CrossRef]

154. Long, L.H.; Evans, P.J.; Halliwell, B. Hydrogen Peroxide in Human Urine: Implications for Antioxidant Defense and Redox Regulation. Biochem. Biophys. Res. Commun. 1999, 262, 605-609. [CrossRef] [PubMed]

155. Banerjee, D.; Madhusoodanan, U.K.; Nayak, S.; Jacob, J. Urinary hydrogen peroxide: A probable marker of oxidative stress in malignancy. Clin. Chim. Acta 2003, 334, 205-209. [CrossRef]

156. Sznajder, I.J.; Fraiman, A.; Hall, J.B.; Sanders, W.; Schmidt, G.; Crawford, G.; Nahum, A.; Factor, P.; Wood, L.D.H. Increased Hydrogen Peroxide in the Expired Breath of Patients with Acute Hypoxemic Respiratory Failure. Clin. Investig. Crit. Care 1969, 96, 606-612. [CrossRef]

157. Loukides, S.; Horvath, I.; Wodehouse, T.; Cole, P.J.; Barnes, P.J. Elevated Levels of Expired Breath Hydrogen Peroxide in Bronchiectasis. Am. J. Respir. Crit. Care Med. 1998, 158, 991-994. [CrossRef] [PubMed]

158. Jöbsis, R.Q.; Schellekens, S.L.; Fakkel-Kroesbergen, A.; Raatgeep, R.H.C.; de Jongste, J.C. Hydrogen peroxide in breath condensate during a common cold. Mediators Inflamm. 2001, 10, 351-354. [CrossRef] [PubMed]

159. Peters, S.; Kronseder, A.; Karrasch, S.; Neff, P.A.; Haaks, M.; Koczulla, A.R.; Reinhold, P.; Nowak, D.; Jörres, R.A. Hydrogen peroxide in exhaled air: A source of error, a paradox and its resolution. EJR Open Res. 2016, 2, 1-8. [CrossRef] [PubMed]

160. Frei, B.; Yamamoto, Y.; Niclas, D.; Ames, B.N. Evaluation of an lsoluminol Chemiluminescence Assay for the Detection of Hydroperoxides in Human Blood Plasma. Anal. Biochem. 1988, 175, 120-130. [CrossRef]

161. Yamamoto, Y.; Brodsky, M.H.; Baker, J.C.; Ames, B.N. Detection and Characterization of Lipid Hydroperoxides at Picomole Levels by High-Performance Liquid Chromatography. Anal. Biochem. 1987, 160, 7-13. [CrossRef]

162. Varma, S.D.; Devamanoharan, P.S. Hydrogen Peroxide in Human Blood. Free Radic. Res. Commun. 1990, 14, 125-131. [CrossRef]

163. Lacy, F.; Connor, D.T.O.; Schmid-Schönbein, G.W. Plasma hydrogen peroxide production in hypertensives and normotensive subjects at genetic risk of hypertension. J. Hypertens. 1998, 16, 291-303. [CrossRef] [PubMed]

164. Deskur, E.; Dylewicz, P.; Rychlewski, T.; Wilk, M.; Wysocki, H. Exercise-induced increase in hydrogen peroxide plasma levels is diminished by endurance training after myocardial infarction. Int. J. Cardiol. 1998, 67, 219-224. [CrossRef]

165. Lacy, F.; Kailasam, M.T.; Connor, D.T.O.; Schmid-scho, G.W.; Parmer, R.J. Plasma Hydrogen Peroxide Production in Human Essential Hypertension: Role of Heredity, Gender and Ethnicity. Hypertension 2000, 36, 878-885. [CrossRef] [PubMed]

166. Wierusz-Wysocka, B.; Wysocki, H.; Byks, H.; Zozulińska, D.; Wykretowicz, A.; Kaźmierczak, M. Metabolic control quality and free radical activity in diabetic patients. Diabetes Res. Clin. Pract. 1995, 27, 193-197. [CrossRef]

167. Tsukimori, K.; Yoshitomi, T.; Morokuma, S.; Fukushima, K.; Wake, N. Serum Uric Acid Levels Correlate with Plasma Hydrogen Peroxide and Protein Carbonyl Levels in Preeclampsia. Am. J. Hypertens. 2008, 21, 1343-1346. [CrossRef] [PubMed]

168. Giulivi, C.; Hochstein, P.; Davies, K.J.A. Hydrogen Peroxide Production by Red Blood Cells. Free Radic. Biol. Med. 1994, 16, 123-129. [CrossRef]

169. Mapson, L.W. Influence of Halides on the Oxidation of Ascorbic Acid. Biochem. J. 1945, 39, $228-236$. [CrossRef] [PubMed]

170. Pirie, A. Glutathione Peroxidase in Lens and a Source of Hydrogen Peroxide in Aqueous Humour. Biochem. J. 1965, 96, 244-253. [CrossRef] [PubMed] 
171. García-Castiñeiras, S.; Velázques, S.; Martínez, P.; Torres, N. Humor Hydrogen Peroxide Dichlorophenol-indophenol. Exp. Eye Res. 1992, 55, 9-19. [CrossRef]

172. Spector, A.; Garner, W.H. Hydrogen Peroxide and Human Cataract. Exp. Eye Res. 1981, 33, 673-681. [CrossRef]

173. Armoza-Zvuloni, R.; Schneider, A.; Sher, D.; Shaked, Y. Rapid Hydrogen Peroxide release from the coral Stylophora pistillata during feeding and in response to chemical and physical stimuli. Sci. Rep. 2016, 6, 21000. [CrossRef] [PubMed]

174. Armoza-Zvuloni, R.; Schneider, A.; Shaked, Y. Rapid Hydrogen Peroxide Release during Coral-Bacteria Interactions. Front. Mar. Sci. 2016, 3, 1-10. [CrossRef]

175. Pick, E.; Keisari, Y. A simple colorimetric method for the measurement of hydrogen peroxide produced by cells in culture. J. Immunol. Methods 1980, 38, 161-170. [CrossRef]

176. Goyen, S.; Pernice, M.; Szabó, M.; Warner, M.E.; Ralph, P.J.; Suggett, D.J. A molecular physiology basis for functional diversity of hydrogen peroxide production amongst Symbiodinium spp. (Dinophyceae). Mar. Biol. 2017, 164, 1-12. [CrossRef]

177. Abrahamsson, K.; Choo, K.; Pedersén, M.; Johansson, G.; Snoeijs, P. Effects of temperature on the production of hydrogen peroxide and volatile halocarbons by brackish-water algae. Phytochemistry 2003, 64, 725-734. [CrossRef]

178. Collén, J.; Jiménez Del Río, M.; García-Reina, G.; Pedersén, M. Photosynthetic production of hydrogen peroxide by Ulva rigida C. Ag. (Chlorophyta). Planta 1995, 196, 225-230. [CrossRef]

179. Patterson, P.C.O.; Myers, J. Photosynthetic Production of Hydrogen Peroxide by Anacystis nidulans. Plant Physiol. 1973, 51, 104-109. [CrossRef] [PubMed]

180. Kalavathi, D.F.; Subramanian, G. Hydrogen Peroxide Photoproduction by A Marine Cyanobacterium Oscillatoria boryana BDU 92181 with Potential Use in Bioremediation. Biosci. Biotechnol. Res. Asia 2013, 10, 929-935. [CrossRef]

181. Suggett, D.J.; Warner, M.E.; Smith, D.J.; Davey, P.; Hennige, S.; Baker, N.R. Photosynthesis and Production of Hydrogen Peroxide by Symbiodinium (Pyrrhophyta) Phylotypes with Different Thermal Tolerance. J. Phycol. 2008, 44, 948-956. [CrossRef] [PubMed]

182. Mishin, V.; Gray, J.P.; Heck, D.E.; Laskin, D.L.; Laskin, J.D. Application of the Amplex red/horseradish peroxidase assay to measure hydrogen peroxide generation by recombinant microsomal enzymes. Free Radic. Biol. Med. 2010, 48, 1485-1491. [CrossRef] [PubMed] 